NBER WORKING PAPER SERIES

\title{
FIGHTING PROCRASTINATION IN THE WORKPLACE: AN EXPERIMENT
}

\author{
Ximena Cadena \\ Antoinette Schoar \\ Alexandra Cristea \\ Héber M. Delgado-Medrano \\ Working Paper 16944 \\ http://www.nber.org/papers/w16944 \\ NATIONAL BUREAU OF ECONOMIC RESEARCH \\ 1050 Massachusetts Avenue \\ Cambridge, MA 02138 \\ April 2011
}

We would like to thank Jordan van Rijn for outstanding collaboration as project associate during the implementation and data analysis of the project and for his excellent contributions to the research, and the participants at the NBER Conference of the Organizational Economics Working Group in December 2010 and at the World Bank's New Ideas in Business Growth Conference 2011 for their comments and suggestions. We thank also Bancamía for their support at all levels and for welcoming us as part of their team during the implementation of the program. We thank the IFC for financial support for the project and ideas42 for funding and operational support. The views expressed herein are those of the authors and do not necessarily reflect the views of the National Bureau of Economic Research.

NBER working papers are circulated for discussion and comment purposes. They have not been peerreviewed or been subject to the review by the NBER Board of Directors that accompanies official NBER publications.

(C) 2011 by Ximena Cadena, Antoinette Schoar, Alexandra Cristea, and Héber M. Delgado-Medrano. All rights reserved. Short sections of text, not to exceed two paragraphs, may be quoted without explicit permission provided that full credit, including (C) notice, is given to the source. 
Fighting Procrastination in the Workplace: An Experiment

Ximena Cadena, Antoinette Schoar, Alexandra Cristea, and Héber M. Delgado-Medrano

NBER Working Paper No. 16944

April 2011

JEL No. D03,G21,J22,J33,L2

\begin{abstract}
$\underline{\text { ABSTRACT }}$
In this paper we test whether procrastination and planning problems affect the performance, compensation and work satisfaction among employees. We conducted a randomized controlled experiment with a bank in Colombia to change the frequency and intensity with which employees received reminders about goal achievements. We also provided small in-kind prizes every week to remind employees of their goal achievement. Loan officers in the treatment group showed strong improvements in their goal achievements, better work load distribution, and higher monthly compensation (not including the value of the small prizes). The intervention also improved worker satisfaction and reduced stress levels, without affecting the quality of the loan officers' portfolios. We show that including branch managers (the supervisors of the loan officers) in the intervention was central in achieving these results, since they played a key role in reinforcing the reminders and helping employees with planning problems.
\end{abstract}

Ximena Cadena

Harvard University

1737 Cambridge Street

Room K 350

Cambridge, MA 02138

xcadena@iq.harvard.edu

Antoinette Schoar

MIT Sloan School of Management

100 Main Street, E62-638

Cambridge, MA 02142

and NBER

aschoar@mit.edu

\author{
Alexandra Cristea \\ ideas 42 \\ alexandra.cristea@gmail.com \\ Héber M. Delgado-Medrano \\ Princeton University \\ 88 College Road West \\ Princeton New Jersey, 08544 \\ hdelgado@princeton.edu
}




\section{Introduction}

A large body of literature in behavioral economics has documented that individuals fall prey to a variety of behavioral biases when making decisions, see for example Thaler (1990). One prominent dimension of behavioral problems that has received growing attention is the tendency of individuals to procrastinate or to compromise long term goals for immediate gratification. That is why people often spend more on short-term consumption at the expense of necessary savings, or do less physical exercise than they might have intended. Examples of such behavior are documented, for example, in Ariely and Wertenbroch (2002) and DellaVigna and Malmendier (2006). Economists have modeled this behavior in the form of hyperbolic discounting as in Laibson (1997) and O’Donoghue and Rabin (1999) or as dual selves as in Fudenberg and Levine (2005). As a result people look for commitment devices that can help them overcome this problem.

But most of the literature has focused on procrastination problems in the context of individual choice and decisions. In their original paper Kahneman and Tversky (1979) define the "planning fallacy” as the behavior by which faced with an unpleasant task, people tend both to underestimate the time necessary to complete the task and to postpone working on the task. Empirical evidence of this fallacy is mostly limited to laboratory or classroom experiments. Brunnermeier et al. (2008) show that people impose deadlines that require less-than-perfect smoothing of work over time, and that self-imposed deadlines increase performance, but not as much as exogenous deadlines that impose perfect work-smoothing over time. Ariely and Wertenbroch (2002) find similar results when evaluating how students allocate their time when studying for a college class. However, almost no research has been conducted to analyze the importance of procrastination and planning fallacies within firms, and the implications for 
employee performance and productivity. One exception is Hossain and List (2009), which finds that framing may have a very important impact on the effects of incentives on performance. Another paper that is closer to our study is Kaur, Kremer and Mullainathan (2010), who look at peer effects in overcoming procrastination and low productivity in the workplace.

In contrast, the vast majority of studies about compensation structures within firms have usually looked at incentives solely through the lens of economic rationality and time-consistency. As a result, these papers focus on how pay can be set to align incentives and overcome moral hazard or information asymmetry problems. The central insight from these agency models is that incentives are better aligned the more pay is sensitive to performance. For example, Buehler et al. (1997) and Bryam (1997) show that monetary incentives can induce rapid completion of tasks. Similarly, Lazear (2000) shows that performance goes up significantly when piece rate contracts are introduced for assembly line workers. However, if we allow for employees procrastinating or being unable to manage their time optimally, end of year or even end of month incentives alone might not help to improve productivity. We could imagine that the periodicity and frequency of pay could matter for employees. For example, smaller but more frequent bonuses could be more effective than one large bonus at the end of the year if employees benefit from frequent reminders of when to exert effort. Similarly the expectation of a bonus in the near future could serve as a better self-commitment mechanism to work hard.

In order to understand the importance of these behavioral issues for the day to day behavior of employees and the implication for optimal contracting, we set up and experiment with a bank in Colombia. The bank identified that their loan officers postpone the sourcing of new clients and credit collection efforts until the last two weeks of each month, just before monthly bonuses are calculated. These instances of procrastination have led to suboptimal timing of cash flows and 
increased costs of cash flow management for the bank, as well as high levels of work-related stress and job dissatisfaction for loan officers. In a baseline survey, 53\% of loan officers reported having difficulties planning their tasks across the month or sticking to their plans, and nearly $70 \%$ reported feeling stressed or very stressed at work, mostly during the second half of the month. The management of the bank was concerned that these high personal costs would lead to lower productivity and burn out of employees.

However, one could argue that what looks like procrastination or planning problems by loan officers could be the outcome of an optimization problem with factors that are unobservable to an outsider. For example, loan officers might have learned that viable clients are only interested in taking a new loan at the end of the month. In that case, loan officers might be unable to front load the loan sourcing tasks if they want to maintain high credit standards. Therefore, the underlying question is whether the incentive system of the bank can be changed to help loan officers plan their work better. Or will such an intervention force loan officers to deviate from the first best and thus have a detrimental impact?

To test these questions, we introduced a new program for loan officers, called Madrugador Program, which was designed to encourage loan officers to shift more of their workload to the beginning of the month. ${ }^{2}$ Through this program, participating employees were eligible to win small prizes for completing sets of credit placement goals during the first two weeks of each month. These prizes were small relative to a loan officers monthly pay and were paid in kind (e.g. movie tickets, restaurant coupons) for an amount that represented only $2 \%$ of the average loan officer's monthly compensation. Moreover, the prizes were independent of the bank's

\footnotetext{
${ }^{2}$ Madrugador is the Spanish word for "early-riser," to bring to mind the idea that the program rewarded those who start performing and completing quotas early in the month.
} 
monthly bonus structure which was preserved unchanged for all employees. Even when the monetary value of the prizes was low, in order to differentiate the impact of monetary incentives from the more behavioral inspired intervention to alleviate procrastination, we introduced incentives for branch managers to encourage loan officers to achieve their early month weekly goals during the second half of the Madrugador program. The branch managers were asked to remind loan officers in their branch about the program, their weekly goals, and update them whether they were on track to achieve their goals or not.

We find that loan officers in the treatment branches show a significant improvement in their task allocation across the month as well as their job satisfaction and stress levels compared to the control group: We find an impact of 30\% improvement in the achievement of goals during the first two weeks of the month due to the Madrugador Program, and a significant tendency to the ideal distribution of loan sourcing throughout the month. There is an average 18\% (10\%) increase in the sourcing of new loans (renewal loans) in the first two weeks of each month. In turn, we also find a small but not significant decrease in loan sourcing in the last two weeks of the months. Thus overall we find no significant change in the level of new loans per month, but we find a strong shift in the allocation of tasks during the month. This shift in loan sourcing does not lead to a change in credit quality since we find no change in the delinquency rate between treatment and control groups after the implementation of the program. It is important to note that these effects did not survive after the intervention was stopped at the end of our experiment ${ }^{3}$. This result serves as an important confirmation that indeed the effect of the intervention is tied to

\footnotetext{
${ }^{3}$ Due to the very positive response of the employees and branch managers the bank is currently in the process of restarting the project on their own.
} 
the actual reminders; it is not the result of a more diffuse shift in the perceived career concerns of loan officers.

However, we find the biggest effect of the program at the individual loan officer level: First, the program had a substantial positive impact on individual compensation. On average, loan officer compensation -independent of program prizes- increased by $25 \%$ per month. This is much in excess of the monetary value provided by the prizes and thus suggests that loan officers were leaving money on the table before the intervention. Therefore, the results suggest that the Madrugador program helped loan officers overcome their procrastination problems and achieve their performance goals while it was being implemented. We also find an economically and statistically significant increase in job satisfaction and a drop in the stress level of loan officers in the treatment group compared to the control group.

Very interestingly our results are only significant in the second half of the experiment where we introduced incentives for branch managers to work with the loan officers to ensure goal achievement through regular reminders. The role of the branch managers in the program is to remind loan officers of their weekly goals and give them updates whether they are on track for achieving their goals. Overall, these results suggest that this intervention, which encourages loan officers to manage and plan their tasks more smoothly over the month, can help them overcome their planning and procrastination issues. Moreover incentives alone do not seem to bring about the desired behavioral changes; they need to be implemented in combination with an organizational structure that provides short term goals to better manage people's time and frequent reminders about the goal achievement. It seems that absent such helpful structures procrastination issues and planning fallacies lead employees to make suboptimal decisions. Our findings underscore that the exact periodicity how incentives are structured, but more 
specifically having an organizational structure to remind and encourage employees to adopt them can have important effects on the effectiveness of compensation schemes.

In the rest of the paper we first outline the context of the experiment and the details of the intervention (Madrugador Program) in sections 2 and 3. Section 4 then describes the data collection and descriptive statistics. Section 5 lays out the findings of our analysis and finally section 6 concludes.

\section{Time Allocation Problem}

The research was conducted with Bancamía, a bank in Colombia that specializes in credit to small and micro businesses. At the time of the intervention, the bank had 61 branches all over Colombia and an average of six loan officers per branch. The total dollar amount of outstanding loans was close to $\$ 160$ million to over 180,000 clients. ${ }^{4}$ The process by which loans are screened is quite effort intensive, since loan officers cannot rely on credit scoring but have to evaluate each new loan applicant and their business in person. Loan officers are required to complete an array of different tasks every month. Their main responsibilities are:

- Promote bank services and products, which entails identifying potential new customers and informing them about the products of the bank.

- Analyze credit applications and assist in the process of loan disbursement, which means visiting the applicant's household and business to gather the necessary information, confirm references given by the applicant and manage the bank internal application process.

\footnotetext{
${ }^{4}$ Bancamía has grown substantially recently, and as of June 2010 had 103 branches.
} 
- Manage delinquent accounts, which entails contacting clients with delinquent loans, often in person, to get them to settle their accounts.

The bank ideally wants loan officers to focus their efforts on the first two activities (promotion of products and credit approval) at the beginning of the month, since loan officers will be required to spend a lot of time on managing delinquent accounts at the end of the month. Therefore, if loan officers do not front load the acquisition of new customers and renewal of existing customers, they are under immense pressure at the end of the month. This could affect the quality of their credit decisions and creates a lot of stress and dissatisfaction. In addition, Bancamía would benefit from improved internal cash management at each of the branches if the loan disbursement occurred more synchronously over the month. Credit repayment takes place mainly at the beginning of the month due to client behavior and institutionally-set payment patterns. However, credit disbursement was heavily occurring at the end of the month, when the loan officers put in more effort. This cash flow mismatch caused extra cash management costs safe values transportation, temporary funding sources, etc. - that could be avoided if loan officers completed their monthly tasks in a smoother way.

To achieve this ideal, Bancamía had tried unsuccessfully different strategies, at the time of the intervention the incentive structure governing the tasks of loan officers at Bancamía is based on a compensation system that includes a base salary and a commission. The commission depends on the completion of monthly goals that vary according to portfolio size and location, for portfolio growth (in number of loans and in pesos value), new loans placed, and delinquency rates. The monthly goals for new loans have weekly targets designed with the objective of balancing the activity during the month. For every week that loan officers fail to meet their targets they are punished with a $5 \%$ reduction of their potential commission. 
In reality the actual time allocation of loan officers deviated quite substantially from the ideal. On average, between January and September 2008, only 15\% of loan disbursements occurred during the first week of the month, while $32 \%$ of loans were disbursed during the last week of the month. In fact, 56 out of the 61 branches existing at that time in Bancamía had more than half of their loans placed during the last two weeks of the month. This problem was prominent not only in a few branches or regions but bank-wide.

This distribution is puzzling from an economic rational perspective. The 5\% punishment for unmet weekly goals built into the compensation structure at Bancamia makes it costly for the loan officers to procrastinate: they are leaving money on the table when they decide to wait until the end of the month to actively pursue customers and try to achieve their monthly targets. But this is not the only reason why being very inactive at the beginning of the month and rushing later to complete their monthly goals was costly for the loan officers. This behavior led to high stress levels and dissatisfaction of employees. For example, in September 2008, 60.3\% of loan officers reported very high levels of stress during the last week of the month. In comparison only $3.4 \%, 1.9 \%$ and $11.2 \%$ of loan officers reported very high levels of stress during weeks one, two and three, respectively. While over $55 \%$ of loan officers felt that leveling out the workload between the beginning and end of the month would improve or greatly improve their level of stress, only less than half of them made detailed work plans at the beginning of the month and follow them.

\section{The Intervention}

The problem identified by Bancamía and the research team was that loan officers seemed to be prone to procrastination problems and tended to leave tasks that did not seem urgent until the end 
of the month. Loan officers had monthly targets and incentives for loan renewal and sourcing of new customers. Even though they knew that they would be busy with collection activities at the end of the month, they left a lot of the loan sourcing activities to the last week of the month as well. This led to boom and bust cycles of high activity and burn out that affected loan officers. In fact, Bancamía had previously tried multiple incentives schemes which, however, proved unsuccessful at alleviating these problems. The main reason for the limited success of prior interventions was that they were behaviorally inappropriate. They consisted mostly of giving high powered incentives for achieving monthly goals and relied heavily on fines and other "stick-type" incentives that demoralized employees.

The Madrugador Program in contrast is built around the idea that loan officers are prone to procrastination problems and do not sufficiently plan their workload over the month. End of the month incentives alone cannot resolve these problems, since they do not help loan officers manage their workload more evenly throughout the month. To tackle the procrastination problem, we designed a set of short term, weekly incentives to reward loan officers for completing specific placement goals during the first two weeks of the month, thus encouraging them to shift part of their workload from the end of the month to the beginning of the month. We focused on positive, small incentives to reward performance. The small, positive incentives were designed to create targets for the first two weeks of the month in order to focus the loan officers' attention on the time management. The prizes were set to be challenging but not unattainable. The cut off for goal achievement that was needed to receive a prize was set at a level which had been attained pre-intervention by roughly $10 \%$ of the loan officers every month. The average loan officer in the sample had to shift at least $8 \%$ of their loan sourcing from the last two weeks of the month to the first two weeks to achieve a prize and up to 37\% to achieve two prizes. All 
loan officers in the treatment group who achieved their goals were rewarded, so each loan officer would have the opportunity to receive two prizes per month, if they met their four goals (new loans and renewals for the first and the second week of the month) during the six months of the program we awarded 284 prizes, on average 1.4 per month per branch. They also provided a constant feedback on whether goals have been achieved or not and thus serve as a reminder so that deadlines do not slip. As part of the program, loan officers were given weekly reminders about their goals and whether they were on track to achieving them. We also distributed the Mardrugador Monthly Bulletin to acknowledge good performers and to keep the program and its objectives salient among participants.

Structure of Incentives: Three types of incentives were used for the program: weekly prizes awarded to loan officers who completed goals for both new credits and credit renewals in the same week (gift certificates worth COP\$30,000 - USD\$15). Also every month we prepared and distributed the "Madrugador Monthly Bulletin," a 2-page full color bulletin featuring the three best performers of the month, mentioning the best performer in each of the participating branches and reminding them about the grand prizes for the best performers throughout the program (a trip for two to a vacation destination in the Colombian Caribbean coast for the best performer and an iPod Nano for the runner-up). Also, half way through every first and second weeks of the month, branch managers met with loan officers to talk about their performance and to remind them their weekly targets and to encourage them to work harder to achieve them. ${ }^{5}$ It is important to note that the new incentive system did not change the overall compensation for loan officers, as the bonus structure remained unchanged. The periodicity in which loan officers

\footnotetext{
${ }^{5}$ Given the limited sample size we were not able to test the differential impact of separate parts of the incentives (weekly prizes vs. grand prizes vs. recognition). Rather, the evaluation of this program focuses on the impact of all incentives as a package
} 
received feedback on their performance did change through reminders and small prizes. In fact, loan officers needed to achieve two weekly goals for loan placement (new loans and renewals) to get the weekly prize that amounted for $2 \%$ of their average monthly salary, and were awarded in the form of gift certificates to go to the movies, to an informal restaurant or to pay for phone calls or at the grocery store. They were never awarded in cash. This suggests that these prizes should not be seen as a very sharp increase in the fraction of pay to performance sensitivity of loan officer compensation. But rather the prizes serve as a constant (positive) reminder that achieving the weekly goals matters.

Setting the goals: Based on the monthly goal structure that Bancamía had in place, we developed weekly goals for the first two weeks of the month, for placement of new loans and for loan renewals. Before the Madrugador Program, Bancamía focused their incentives for loan sourcing only on new loans and did not take into account renewal loans. We created specific goals for renewal loans and used the existing monthly targets for new loans to create weekly goals for both indicators. All these goals depend on factors like the portfolio size and geography of the branch and the characteristics of the community covered by the loan officer (i.e. large urban community urban, small urban community and rural community) which affect the difficulty of sourcing customers. The weekly goals were designed according to Bancamía's desired ideal distribution of monthly credit placement concentrated towards the beginning of the month: By the end of the first week of the month they should place $35 \%$ of their monthly target, and by the end of the second week $60 \%{ }^{6}$

\footnotetext{
${ }^{6}$ Ideally they would complete $80 \%$ of the monthly target by the end of the third week, and $100 \%$ by the end of the month. However, the program did not give specific targets or incentives for weeks 3 and 4 .
} 


\section{Sample Set-up and Research Design}

To rigorously test the impact of the Madrugador Program on the performance of branches, we stratified the 61 branches of Bancamía by geographical areas (Northern Bogotá, Southern Bogotá, Cundinamarca/Boyacá, Northern Medellín, Southern Medellín and Antioquia/Caldas) and then within each geographic area randomly assigned half of the branches to the treatment group and the other half to the control group which did not receive any incentives. We end up with a group of 31 regionally representative branches that are randomly assigned to the treatment. The other 30 branches did not receive any intervention and thereby constituted the control group for the evaluation.

While the incentives were designed to reward individual performance, the intervention was implemented at the branch level so that all employees at a given branch either had the opportunity to receive the prize or not. It was important to ensure equal treatment for loan officers working within the same branch. Although loan officers are responsible for their own portfolio and receive commissions based on individual performance, the bank management did not want to create tensions or a feeling of inequality in the branch. Also, for logistic purposes the bank wanted to restrict the amount of interference that the project could cause with regards to the communication that is needed, training of loan officers about the incentives scheme and the requirements they had to meet to be rewarded, delivering mid-week reports to inform loan officers about their performance, etc.

We conducted the experiment in the period from November 2008 to April 2009. We added an additional feature to the treatment after the first three months of implementation: Starting in February 2009, branch managers were included in the incentives scheme so that they would 
receive monthly awards if their branch met $50 \%$ of the set goals, grand prizes if their branch performed best overall, as well as monthly acknowledgements in the Madrugador Monthly Bulletin. This additional incentive was added since after preliminary analysis of the results of the program, it seemed like it was organizationally more effective if the managers received incentives as well to reinforce their role as agents of the program, reminding and encouraging loan officers to achieve their monthly goals. Moreover, employees would perceive it as fairer if all the employees at the branch were part of the treatment.

\section{Data}

The data for this study comes from two different sources: We obtain monthly and weekly financial indicators at the branch level from Bancamía’s internal IT system. The variables collected are the number of loan officers and prize winners per branch, number of loans per branch, branch characteristics, portfolio composition, delinquency rates, credit placement and loan officer compensation data. We use administrative data from Bancamía for all 61 branches existing at the beginning of the program from July 2008 to April 2009. The time period can be divided into two main sub-periods: the pre-treatment period from July to October 2008, and the post-treatment period from November 2008 to April 2009. The post-treatment period, in turn, can be divided in two: Form November 2008 to January 2009 when only loan officers were subject to the incentives, and from February to April 2009 when branch managers were also included and awarded by the performance of their teams. We also collected available administrative information for a post-intervention period between October and December 2009. 
Also, we conducted baseline and end-line surveys to gather information regarding participants' personal and socioeconomic characteristics, as well as stress levels, job satisfaction, and work practices and during the end-line survey, their perceptions about the program. The baseline survey was conducted in September and October 2008. The surveys were conducted by a professional survey firm over the phone. Loan officers were contacted first by the bank to alert them that the survey was to be conducted and then the company followed up with a survey call. The response rate to the baseline survey was $98 \%$. Data is available for loan officers who were working at the participating branches before the implementation of the program (388 people in 61 branches). The end-line survey was conducted in May 2009, We followed the same procedure and had a response rate of $96 \%$. However, during the time period in question, Bancamía went through a rapid growth period and thus experienced a lot of promotions and moves between branches. As a result $66 \%$ of the loan officers, who were interviewed in the baseline period, were still in the sample at the time of the end line survey. ${ }^{7}$

\section{Branch and Loan Officer Characteristics}

Before the start of the program, Bancamía had on average six loan officers per branch who worked on loan promotion, analysis, disbursement, and recovery. On average, each loan officer managed a portfolio of 500 loans and sourced about 35 new loans every month. Panel A of Table 1 shows details about portfolios and loans disbursement activity at the branch level. It shows that our randomization was successful since treatment and control branches were statistically not different from each other: Both groups have branches with very similar age and portfolios, the mean portfolio for the branches in the control group is COP\$5.1 billion (about $\$ 2.0$ million) it is

\footnotetext{
${ }^{7}$ We analyze attrition when we use loan officer level data to measure impact on individual well-being in Section V, sub-section d. of this paper.
} 
COP\$5.6 billion ( $\$ 2.3$ million) for the treatment branches, the difference is not statistically significant. The groups have very similar shares of rural loan officers and agricultural loans, almost identical monthly activity per loan officer on average regarding new loans and loan renewal placement, etc. They also have very similar behavior in terms of delinquency rates. The average Bancamía branch has a delinquency rate of $11.1 \%$ of its outstanding credits. For offices in the treatment and control groups, the average delinquency rate is $11.2 \%$ and $10.9 \%$, respectively, and we do not find any statistically significant difference between the two groups.

In Panel B of Table 1, we show personal characteristics for loan officers. The average loan officer working at Bancamía is 29 years old, $70 \%$ of them are between 25 and 35 years old. About $47 \%$ of them are women. Loan officers have high levels of education, since Bancamía requires them to have obtained a technical or professional degree in an administrative area, or to be enrolled in the seventh or higher semester of a university program in this field. More than $80 \%$ of loan officers have university $(60 \%)$ or technical $(15 \%)$ degrees and some of them ( $7 \%$ of the total) have a Master's or other graduate level education. On average, loan officers have 15 years of education. This educational attainment level is significantly above the country average, since the average Colombian receives 9 years of education. The differences between age and education levels are not statistically significant when comparing treatment and control groups. Before the start of the Madrugador Program, the average experience of loan officers working at Bancamía was 19.9 months. 61.3\% had worked in Bancamía for a period between one and three years and only $4.9 \%$ had been working there for more than three years. $34 \%$ of loan officers had been at Bancamía for less than one year. It is possible that people who are relatively new to their job are more open to learn and reorganize their time and therefore are more susceptible to incentives to do so. Even though the average time at Bancamía is statistically identical for loan 
officers in the treatment and control group, the percentage of analysts that have been there for less than one year seems to be different between the groups (38\% in the treatment vs. $29 \%$ in the control). Loan officers at Bancamía reported feeling stress about their work 33.3\% of the time. Nevertheless, a relatively high percentage of them (31.5\%) said that they never felt stressed or burnt out as a result of their work, while $27 \%$ said that they felt stressed or burnt out as a result of their work more that $50 \%$ of the time. There are no statistically significant differences for the distribution of stress between treatment and control groups.

Loan officers get paid a basic salary that depends on experience and seniority and a bonus that depends on monthly performance. The bonus is about $35 \%$ of the total salary that ranges between 1.3 and 2 million pesos $(\$ 608-\$ 1,000)$. The weighted average for the month before the implementation of Madrugador Program was 1.5million (US\$800) and statistically identical between treatment and control groups. ${ }^{8}$

\section{Incentives for Fighting Procrastination: Impact on Outcomes}

We now analyze the impact of the Madrugador Program on branch level outcomes. The estimation strategy uses a difference in difference estimator of the impact of the treatment on the treated branches compared to the branches in the control group relative to their performance in the pre-treatment period. We subdivide the treatment period into the first three months of the treatment when only the loan officers received incentives and a separate dummy for the next

\footnotetext{
${ }^{8}$ Weekly incentives were small and represented only $8 \%$ of the average weekly salary.
} 
three months when the branch managers also received incentives. All specifications include branch and month fixed effects and we cluster standard errors at the branch level. The general specification is

$$
Y_{i t}=\beta_{o}+\beta_{1} T_{i t}+a_{i}+c_{t}+\varepsilon_{i t}
$$

Where $Y($ it) are different outcome variables for branch $i$ in period $t, T(i t)$ is the treatment indicator - a dummy variable that equals 1 for the branches in the treatment group during the treatment period, and zero otherwise - $a$ and $c$ are vectors of branch and month fixed effects, respectively. $\varepsilon$ is the error term. As mentioned, we split up the treatment period into the first three months when only loan officers received incentives and then the next 3 months of the experiment when their branch managers were also included in the incentives. Going forward we will allow for two separate dummies for the two subperiods. For a detailed description of the variables used on this section, please refer to Appendix 1. For the variables where data was available, we also included a post-intervention period to test for persistence of effects after the program stopped. The post intervention dummy takes the value of 1 for treatment branches in the post intervention period and zero otherwise ${ }^{9}$.

\section{a. Redistribution of tasks: Loan origination during the first two weeks of the month}

The main objective of the program was to encourage loan officers to smooth their efforts generating new loans and loan renewals over the month, so that they spend more time upfront on

\footnotetext{
${ }^{9}$ The bank went through a data management system in September 2009, and all past detailed data for loan activity within the month was lost. When we requested the post intervention data we could only get detailed data for the period after October 2009.
} 
these tasks and less in the last two weeks of the month. To measure the direct impact of Madrugador Program we first look at the number of loan officers in each branch and each month who achieved the stipulated goals set out by the program, i.e. loan officers who show the desired increase in new loans and loan renewal in the first or second week of the month. People who achieve these goals in the branches of the treatment group would receive the incentives. Branches in the control group were not given any specific goals to complete, but we can use data on the number and timing of credit origination for each loan officer in the control group to determine who would have won prizes had goals been established in their branches. ${ }^{10}$

Columns 1 and 2 of Table 2 show the empirical results for the basic specification. In column 1 we use a dummy equal to one for the entire treatment period (November to April) for the branches in the treatment group. The size of the coefficient is economically large, 0.308, which indicates a 30 percent increase in the likelihood that loan officers in the treatment braches achieve their weekly targets compared to the control group. However the coefficient is not statistically significant when allowing for clustered standard errors. We then include in Column 2 separate treatment effects for the first three months of the experiment (November to January) and another dummy for the next three months (February to April). The difference between the periods is that from February to April of 2009, not only loan officers, but branch managers were also included into the incentives scheme. We find a strong differential effect in this second period: branches in the treatment group experience a statistically significant 0.7 increase in target achievement relative to the control branches. In contrast we find a small and insignificant effect

\footnotetext{
${ }^{10}$ In this section, goal completion is equivalent to the number of loan officers that carried out their placement of credits according to the $35 \%$ and $25 \%$ distribution in weeks one and two, respectively. However, it should be clarified that within control group branches, and in both groups prior to the start of the program, there were no goals to complete; therefore, the use of the term "goal completion" is a simplification that is used in order to facilitate the presentation of results. More accurately, goal completion in these non-program scenarios represents the number of goals that would have been completed had there existed a program, given the credit placement history of each loan officer, their portfolio size, and their portfolio category.
} 
for the first three months when the branch managers had not been included in the treatment goals. In Columns 3 and 4 of Table 2 we repeat the same regressions but include controls for the number of loan officers at the branch, the types of loan (agricultural loans versus small urban business loan) and previous levels of portfolio and delinquency rates. The results are unchanged and if anything become slightly more significant. ${ }^{11}$

In columns 5 to 10 of Table 2 we now report the results for a related outcome variable which measures how far loan officers in each branch are from the ideal time distribution of loan placements over the month. Based on Bancamía guidelines to their loan officers and the incentive structure introduced with Madrugador Program, we define the "ideal" credit placement distribution throughout the month as: $35 \%$ of credits placed in the first week, $25 \%$ in the second week, $20 \%$ in the third week and $20 \%$ in the fourth week. Given the total number of loans placed in a specific month and the "ideal" weekly distribution of those loans across a month we compute the "ideal" distribution. For each week, we then take the difference between the actual number of loans placed and this ideal distribution and square these differences. This "gap indicator" is the sum of the squares of these differences for each week for the four weeks of the month. Thus, a lower index suggests a closer approximation to best-practices behavior.

\footnotetext{
${ }^{11}$ The empirical results also provide interesting information concerning other variables that affect the completion of goals. For instance, as the portfolio size of a branch grows, goal completion also rises. This is a compelling result, given that as portfolio size increases, the goals become harder to achieve. Moreover, for every additional percentage point increase in delinquency rate in a branch, the completion of goals decreases by almost four completed goals. As delinquency rates rise, the foremost preoccupation of loan officers will likely be the reduction of delinquency. Therefore branches might have fewer resources (in terms of time and willingness) to increase loan placements in the first two weeks of the month. This last finding confirms that delinquency rates are a problem not only in terms of increased financial costs for the bank, but also an impediment to the redistribution of loan placements towards the beginning of the month.
} 
The regression specifications in columns 5 to 8 are parallel to columns 1 through 4 . The basic empirical results are presented Columns 5 and 6 show a significant reduction in the distance to the ideal distribution for the treatment branches due to the Madrugador Program. The treatment group shows a reduction in the distance to the ideal by almost $12 \%$ for the total period of treatment. When we again break out the two subperiods we can see that the inclusion of branch managers had an even stronger and more significant impact in the second period. The estimated coefficient goes from -6.7 for the entire treatment period to -9.6 for the sub-period. The results become even stronger when including additional controls in columns 7 and 8 . In columns 9 and 10 we include the post-intervention period to test for persistence of effects after we stopped program implementation. The coefficient on the post-intervention dummy is close to zero and not significant for any of the specifications. Once the competition and the reminders were removed, loan officers reverse their tendency to distribute the work load more evenly across the month.

Overall, these results suggest that the introduction of incentives led to a significant change in the way loan officers allocate their time across tasks and brought it more in line with the desired allocation over a monthly period. We also see that the inclusion of managers in the program has a strong, positive impact on the performance of loan officers. In our end-line survey for loan officers we explore several channels through which branch managers might have had an impact on motivation. Of the participating loan officers, 50\% said that their branch manager reminded them about the program at least once a week, while 59\% declared that their branch manager showed them the weekly report - a document in which we kept track of performance halfway through the week to let participants know how they were doing and what they needed to do to 
accomplish their goals. Moreover, $48 \%$ of loan officers revealed that their branch manager talked to them on a weekly basis with regards to weekly prizes, while $28 \%$ say that their branch manager talked to them about the grand prizes also on a weekly basis. Basic regression analysis (not reported) showed that there is a positive and statistically significant correlation between how much branch managers talk about the program and used the monthly bulletin as a motivational tool and goal completion. Both motivation and information about the program seemed to be useful tools for managers to improve loan officers' performance.

\section{b. Branch level impact: Productivity and delinquency rates}

We now analyze whether the change in the time allocation of activities across the month also affected the productivity of the loan officers or the quality of their decision-making. One might worry that the program could lead to suboptimal outcomes overall if loan officers were previously using an optimal time allocation and the treatment interfered with the timing preferred by the loan officers. These timing effects might even change the quality of loans made and as a result increase delinquency rates. The goal was that the program should help to redistribute the workload over the month, and as a result loan officers would have more time for loan assessment at the beginning of the month and for loan-recovery at the end of the month. This could lead to a reduction in delinquency rates both current and future. But if the program forced loan officers to deviate from the first best time allocation in order to smooth activities over the month, they might have been compelled to place loans just in order to meet program goals irrespective of the

client quality. A possible explanation for such an outcome would be if only a few high quality customers were looking to take a loan at the beginning of the month. In this section we therefore explore the impact of the program on productivity and delinquency rates. 
Results in Table 3 show the effect of the treatment on the overall level of loans that are sourced by the loan officers and then break down between the number of new loans versus the number of renewal loans (a new loan to an existing customer). We again break out the treatment effects for the first three months and the second three months of the treatment period. Columns 1 to 3 show the results of the treatment on the total number of loans sourced by branch over the entire month, the number of new loans sourced, and the number of loans to renewal customers, respectively. We do not find a significant treatment effect in any of the loan categories. While the estimated coefficients are generally positive and economically meaningful, the standard errors are too big to make any conclusive inference. However, when we breakout the effect for the first two weeks of the month, which is the time period that Bancamía wanted the loan officers to increase their loan sourcing activities, we find positive and significant effect on the credit placement performance in treated compared to control branches. Column 4 reports the results using the number of all loans sourced per loan officer in the first two weeks of the month as the dependent variables. The size of the effect is economically significant, about one more loan per branch during the first two weeks of the month, and is significant at the $10 \%$ level. In column 5 we now break out the new loans sourced per loan officer in the first two weeks of the month. We see that new loans make up a little more than $60 \%$ of the increase in loans over the month and the effect again is significant at the $10 \%$ level. Finally, in column 6 we see that the effect on the renewal loans in the first two weeks is positive but economically smaller than on the new loans (the coefficient is 0.4 ) but is not significant at conventional levels. In columns 4a and 5a we see that the effects only lasted while the program was being implemented, so loan officers' behavior reverted back to usual in the post-intervention period. And finally in columns 7 through 9 we 
report the results when including only the last two weeks of the month. We see that across all three measures of loan sourcing activity the effect for the treatment group is negative but not statistically significant. Even the negative coefficients on the treatment effects for the second half of the treatment period are about half the size in magnitude compared to the positive coefficients in the first two weeks of the month (columns 4-6).

Overall the results suggest that the program incentives led to a significant shift of loan sourcing activities over the month and toward the desired distribution by Bancamía. Loan officers engage in more loan sourcing and renewal at the beginning of the month but reduce these activities in the second half of the month. It is in particular interesting that treatment impact was strongest on the effort of sourcing new loans in the first two weeks of the month. While these efforts did not translate into significant overall increases in loan officer productivity during the treatment period it is possible that over a longer time period this can lead to significant improvements for loan officers when these new loans come up for renewal in the future.

As discussed before, we now test whether these changes in the composition of activities over the month had a detrimental effect on the quality of loans that were made. Table 4 shows the results for the monthly level of delinquent loans at the branch. Since we do not have delinquency information for individual loans, we do not know when a particular loan was originated (or by which loan officer) that is becoming delinquent in a given month. Therefore we only focus on the average level of delinquency rates at the branch level. In column 1 the dependent variable is the delinquency rate as measured by the total value of credit that is at least one day late divided by the total value of credit outstanding at the branch. Parallel to our standard specification we 
regress the delinquency rate on dummies for the two treatment periods and our usual control variables. While we see that the overall delinquency rate in the portfolio of Bancamía increased over the time period, we do not find any impact of the treatment on delinquency rates. In fact the estimated coefficients are very close to zero and the standard errors are big. In columns 2 and 3 we now repeat this regression but calculate the delinquency rate based on loans that are 30 days late or less and those that are more than 30 days late, respectively. As before the coefficient on the treatment dummies is very close to zero and not significant.

One might worry that using contemporaneous delinquency rates in columns 1 to 3 unfairly attributes negative (or positive) loan performance to branches in the treatment period, when in fact many of these loans were sourced long before the treatment was implemented. If loans in general take a few months to reveal their true credit quality, using contemporaneous delinquency rates might distort our findings. Therefore in columns 4 to 6 of Table 4 we now repeat the same estimation as in the first three columns but we assume that there is a two-month period when a new loan would start showing problems. That means: to capture the quality of loans that were initiated in a given period we looked at the performance of the loan portfolio two months out. The results under this approach are unchanged from before. Again, we do not find a significant impact of the Madrugador Program on loan delinquencies. ${ }^{12}$ It seems like Madrugador Program was successful in shifting workload towards the beginning of the month, without affecting delinquency indicators.

\footnotetext{
${ }^{12}$ We also did the analysis (not reported) using short term delinquency rates (30 days late or less) in the future (one month, two months, three months out and some combinations) and we did not find significant results for any impact of Madrugador Program on future delinquency rates.
} 


\section{c. Impact on Loan officers' Compensation}

We now look at the impact of the Madrugador Program on the individual compensation levels for loan officers. In the previous subsection we showed that although there was a shift on activity from the last weeks of the month to the first two, there was not overall statistically significant impact on monthly productivity or delinquency rates at the branch level. However, the Madrugador Program had a positive impact on the general time allocation and the portfolio performance of individual officers. We estimate the impact on individual total compensation and bonus for people in the treatment and control groups. If loan officers prior to the experiment were optimally extending their effort, a minimal change in incentives (the in kind prizes) should not lead to large changes in compensation, since this compensation level could have previously been attained given that the overall bonus structure of the bank did not change. We use data from the bank’s internal Management Information System to track loan officer compensation over time. We gathered data for all loan officers in participating branches (treatment and control) for the period June 2008 to April 2009. We have a panel data at the individual level that allow us to calculate the treatment effect using an estimation strategy analogous to the difference-indifference one described by equation (1). As in the case of the branch level estimations, we include branch and fixed effects and we cluster standard errors at the branch level.

Table 5 shows the results for regressions estimating the impact of the program on total compensation and bonuses earned monthly by the loan officers. The program had a positive and significant impact, allowing loan officers to optimize their activities and receive a higher pay (excluding small Program prizes). Columns 1 to 4 show the basic results. After controlling for branch and period trends, and personal characteristics, loan officers in the treatment group increased their total compensation by an amount between COP $\$ 334,133$ and COP $\$ 421,469$ 
(\$152- \$191) relative to the trend observed by their counterparts in the control group. The average compensation for the total sample is COP\$1,497,882 (USD\$682). The treatment accounted for an increment on total compensation by about $25 \%$, just by changing the behavior of loan officers without affecting the compensation structure. As usual, we show the results for the two sub-periods in the treatment group and for specifications controlling for observable characteristics. The results are robust also when we only include people who stayed at the bank for seven or more periods out of the 11 months included in the analysis (column 5). Colum 6 shows the results for the variable in logarithms, reiterating the treatment impact effect around 30\%. Column 7 includes the results for the bonus. All treatment estimates are statistically significant at a $1 \%$ significance level. The results are robust to different specifications, samples and measures of compensation. Madrugador program had a positive and significant effect on loan officers' compensation independent on the small prizes awarded as incentives to shift behavior. However, as we showed for the gap indicator and the productivity measures, the effects of the program disappeared once the competition and reminders stopped. This evidence suggests that loan officers were leaving money on the table before Madrugador program was implemented; they improved while the program was in place, but got back to previous behavior afterwards.

\section{d. Impact on Loan officer's Well-Being: Satisfaction and Stress Levels}

One of the assumptions and goals behind the Madrugador Program was that if participating loan officers effectively improve their planning behavior and redistribute their workload, they would avoid exhaustion at the end of the month and experience higher satisfaction and less stress than their peers in the control group. To explore the impact of the Program on loan officers' well- 
being, we use individual loan officer data. We use the responses from the surveys that we administered before and after the implementation of the program to analyze the impact on work satisfaction, satisfaction with the compensation, planning behavior and stress. These variables are person specific and hard to aggregate at the branch level.

\section{Treatment Effect on Loan officer job satisfaction and Stress Levels}

The estimation strategy for the individual loan officer data uses a difference in difference estimator of the impact of the treatment on the treated loan officers compared to the loan officers in the control group relative to their baseline characteristics. As before, we cluster standard errors at the branch level. The general specification is

$$
X_{j t}=\beta_{o}+\alpha X_{j t-1}+\beta_{1} T_{j}+\varepsilon_{i t}
$$

Where $X(j t)$ are well-being variables for loan officer $j$ in period $t$, where $t$ is post-treatment period and $t-1$ is pre-treatment (baseline) period. $T(j)$ is the treatment indicator - a dummy variable that equals 1 for loan officers in the treatment group, and zero otherwise. $\varepsilon$ is the error term.

Table 6 shows the results for satisfaction with work and satisfaction with compensation. In the surveys we asked the loan officers to rate their levels of satisfaction with work and compensation in a scale from 1 to 5 where 1 is very unsatisfied, 2 unsatisfied, 3 neutral, 4 satisfied and 5 very satisfied. We use these responses to create indicator variables that identify people who reported being satisfied or very satisfied, and estimated probability models (probit) for work satisfaction 
and satisfaction with compensation reported in columns 1-2 and 5-6 respectively. ${ }^{13}$ Results show that the probabilities of being satisfied or very satisfied with work and compensation were higher for loan officers in the treatment group at the end of the program, controlling for satisfaction levels at baseline and personal characteristics. The coefficients are statistically significant at a $10 \%$ significance level and are between 0.2 and 0.4 . We see that the program caused an increment on the level of work satisfaction of five percentage points and of six percentage points in the level of satisfaction with the compensation. It seems that the awards improved participants' motivation and employees seem to enjoy the weekly prizes, further improving work satisfaction and satisfaction with the compensation. This is interesting since even when the program did not change the compensation structure, as we showed earlier, it did help loan officers in the treatment group to be more effective and claim higher compensation relative to their piers in the control group. Columns 3-4 and 7-8 confirm these conclusions. They show results for ordered probit regressions for satisfaction with work and compensation using the original scale of 1 to 5 with 1 being very unsatisfied and 5 very satisfied.

We now turn to analyze the reported level of stress at the work place in response to the treatment. On the one hand, if the participating loan officers become better planners and manage to level their workload between the beginning and the end of the month, they would consequently experience less stress. On the other hand, it is possible that the new goals imposed more demands thus raising the level of exhaustion for them. We first explore the impact of Madrugador Program on planning levels. According with their answers to the surveys, loan officers are divided between those who do not make work plans, those who make plans but do not follow them, and those who make plans and follow them. Table 7 shows in columns 1-2 the

\footnotetext{
${ }^{13}$ Main results are unchanged when using linear specifications.
} 
estimations of the probability of making a work plan every month and following it. The results show that loan officers in the treatment group are more likely to do so, controlling for planning behavior pre-treatment and personal characteristics. In fact, their probability of improving their planning levels or keeping them high was 8 percentage points higher than that for the control group (columns 3-4). Consistent with the results on planning behavior, loan officers in the treatment group experienced a change in the time they feel stressed at work five percentage points more favorable than their peers in the control group (columns 5-6). This relation between planning and stress coincides with loan officer perception: 53\% of them declared at the time of the survey that leveling the work-load between the beginning and the end of the month would help them "a lot" or "tremendously" to reduce work-related stress.

In unreported regressions we also looked at heterogeneous treatment effects of the Madrugador Program along dimensions such as gender, age and education. We do not find any evidence that the treatment effects are affected by those characteristics. It is interesting that the program seems to have uniformly impacted loan officers independent of personal characteristics. The results are also reassuring in light of the above-mentioned attrition of loan officers out of the treatment and control groups (due to lateral moves). They suggest that there is no differential impact of the treatment based on the observable characteristics of the loan officers. This is reinforced by the fact that treatment and control groups are comparable before and after attrition happened (see next section and Table 9).

\section{Attrition Rates}

To estimate the treatment effect, we look at the responses of loan officers who stayed at the branches for the duration of the Madrugador Program and answered both the baseline and the 
endline surveys (256 people out of 388 - attrition: 34\%). Of the 256 respondents in both waves of the survey, 136 are in the treatment group and 120 are in the control group. The attrition rate out of both treatment and control groups is very similar and quite significant (35\% and 34\% respectively). Unfortunately we were not able to prevent the bank from moving loan officers laterally within branches, since this would have interfered significantly with the bank's growth objectives. However, contrary to the usual forms of attrition in randomized controlled trials, in this case, it was mainly a function of the rapid expansion of Bancamía overall during this period when many loan officers experienced lateral moves and were relocated to new branches. To verify the nature of the sample that exits the study, we analyze the characteristics of people who stayed in both samples. Table 8 compares the characteristics at baseline of the group of loan officers who were at the bank at the beginning of the program and those who stayed at their branches through the duration of the program. There is a higher proportion of women in the group that answered only the baseline (58\%) compared to the group that we are using to measure the impact ( $41 \%$ of women), the difference is statistically significant. Also, people who stayed in the branch through the completion of the program are about one year older and have about 0.4 years less years of education than the loan officers that moved out of a branch (15.3 vs. 14.95). Even though statistically significant, the economic size of the differences for age and years of education is very negligible. All other observable characteristics are not statistically different between the two groups. While overall there is slightly higher likelihood that female, (one year) older, and slightly more educated loan officers move to another branch, these transitions are homogeneous across treatment and control groups. We see in Table 9 that the baseline characteristics of the loan officers who remain in the treatment and the control groups after the exit of the movers are statistically not different at the $5 \%$ significance level along most 
dimensions. ${ }^{14}$ Comparing with the initial distribution between treatment and control groups (discussed in section 3 and presented in Table 1), we see that the attrition of loan officers from the treatment and control groups does not seem to have been through a selection on any observable characteristics of the loan officers but rather was conducted by the bank in a random way.

\section{e. Perceptions about Madrugador Program}

As a final step we analyze how the participants in the treatment group perceived the effectiveness and success of the Madrugador Program. In our end-line survey we asked loan officers and branch managers in the treatment group how they rated the experience overall, and which aspects of the program they enjoyed the most. Overall, the reaction was positive, with $68.3 \%$ of loan officers and $89 \%$ of managers responding that they liked the initiative. Loan officers seemed to agree on which program characteristics they enjoyed the most: more than $85 \%$ of them said they appreciated the opportunity to win the Madrugador prizes. Furthermore, the prestige element brought about by the monthly acknowledgements seems to have been crucial: $84 \%$ of survey participants enjoyed being able to share the prizes and acknowledgements with their friends and family, while $74 \%$ said they appreciated the possibility of being publicly praised for their work. It is therefore no surprise that $76 \%$ of the participants liked the monthly bulletin feature of the program.

\footnotetext{
${ }^{14}$ The only exception is the percentage of time a loan officer felt stressed or burnt out at baseline. This difference means that relatively more loan officers that reported being stressed at baseline left their branch in the control group than in the treatment group. The difference is small and only marginally significant. But it would suggest that any possible bias should go against us: the Program was successful at retaining more stressed loan officers and helping them manage stress levels.
} 
But we also wanted to understand whether the additional incentives affected the interpersonal relationships of branch employees or even created additional stress. Of the participants in the treatment branches, $49.1 \%$ liked the friendly competition within their branch, $44.5 \%$ were indifferent to it, and only $6.4 \%$ disliked it. Additionally, $41 \%$ enjoyed the competition between the branches, $57.2 \%$ were indifferent and $1.7 \%$ disliked it. Furthermore, $63 \%$ of participating loan officers declared that the competition generated by the Madrugador Program had a positive impact on the work environment. In fact $61 \%$ of the participating managers declared that workrelated behavior in their branches had changed positively as a result of the Program.

In addition, the program appears to have made loan officers more aware of their work goals and of the distribution of their workload over time: $82.9 \%$ of the participants declared they were more aware of their placement goals compared to six months beforehand, and $80.3 \%$ of them said they were more aware of their placement distribution throughout the month than six months prior. The positive effects of the program on satisfaction and stress and well-being in general presented in the previous section are consistent with managers' and loan officers' perceptions: all managers agreed that Bancamía should implement the Madrugador Program on a permanent basis, and $76.3 \%$ of loan officers agreed as well.

\section{Conclusions and Recommendations}

The Madrugador Program's stated objective was to shift credit placement from the end to the beginning of the month. We find that the intervention was effective in shifting the behavior of loan officers without affecting total productivity or delinquency rates. This is reflected in the evolution of completed goals, monthly distribution gap indicators, and weekly productivity 
within the treatment group compared to the control group. In addition we find an increase in loan officer productivity with respect to loan sourcing and generation of new clients over the first half of the month, but a reduction in the last two weeks of the month. The program also significantly increased job satisfaction, improved the loan officers' planning behavior in managing their tasks over the month, and reduced their overall work-related stress levels. Importantly, the program did not significantly impact delinquency rates or total productivity, suggesting that the intervention achieved the redistribution of the workload and a higher level of employee wellbeing without negatively affecting crucial financial indicators for the bank. In fact, the program improved the overall performance at the individual level, reflected on higher bonuses and compensation, independent of program prizes. Ideally, we would have liked to see retention as part of the outcome variables from the program, but due to the high number of lateral moves in the bank overall, we cannot cleanly measure this variable.

Furthermore, our results strongly suggest that the positive effects from the program materialized only after branch managers were included in the new, behaviorally-sensitive incentive scheme. Giving incentives only to loan officers without the reinforcement and encouragement of the branch managers seems to have no significant effects. This result supports the interpretation that our intervention changed loan officer behavior mainly through the positive encouragement through prizes coupled with weekly reminders and public recognition. But it seems that incentives alone (even if given at a higher frequency) are not sufficient to help loan officers overcome their procrastination problems. In fact, the effects disappeared after the competition and reminders stopped, which suggests that the results are not driven by a shift in the perceived long run career concerns of loan officers but by the weekly reminder and incentives that help loan officers focus on the goals 
The results can also contribute to the larger debate of whether centrally designed programs can help individuals overcome behavioral problems or if these programs invariably restrict the freedom of the individual. At least in the case of the Madrugador Program, these small nudges helped loan officers improve their performance and also increased their satisfaction at work. Even when asked directly about their perception of the program, the majority of loan officers had a positive impression of the program. 


\section{References}

Ariely, D., and Wenterbroch, K. (2002). "Procrastination, Deadlines, and Performance: SelfControl by Precommitment” Psychological Science 13, pp. 213-224.

Ashraf, N., Karlan D., and Yin, W. (2006). "Tying Odysseus to the Mast: Evidence From a Commitment Savings Product in the Philippines," Quarterly Journal of Economics, Vol 121 May p.635-672.

Buehler, R., Griffin, D., and MacDonald, H. (1997): “The Role of Motivated Reasoning in Task Predictions”, Personality and Social Psychology Bulletin, 23, pp. 238-47.

Brunnermeier, M., Papakonstantinou, P., and Parker, J. (2008). “An Economic Model of the Planning Fallacy”, NBER Working paper \#14228.

Byram, S. J. (1997). “Cognitive and Motivational Factors Influencing Time Prediction”, Journal of Experimental Psychology: Applied, 3(3), pp. 216-39.

DellaVigna, S., and Malmendier , U. (2006). "Paying Not To go To The Gym," American Economic Review, June 2006, Vol. 96, pp. 694-719.

Fudenberg, Drew, and David K. Levine, “A Dual Self Model of Impulse Control,” Harvard mimeo, 2005.

Hossain, T. and List, J (2009). “The Behavioralist Visits the Factory: Increasing productivity using simple framing manipulations.” NBER Working Paper \# 15623.

Kahneman, D. and Tversky, A. (1979). "Intuitive Prediction: Biases and Corrective Procedures”, in Forecasting, ed. by S. Makridakis and S. C. Wheelwright, pp. 313.27. North-Holland, TIMS Studies in Management Science 12.

Kaur, S., Kremer, M. and Mullainathan, S. (2010). "Self Control and the Development of Work Arrangements”, working paper 2010.

Laibson, David I., “Golden Eggs and Hyperbolic Discounting,” Quarterly Journal of Economics, CXII (1997), 443-477.

Lazear, Edward P. (2000). "Performance Pay and Productivity," American Economic Review, American Economic Association, vol. 90(5), pages 1346-1361, December

O'Donoghue, T. and Rabin, M. (1999). "Incentives for Procrastinators," The Quarterly Journal of Economics, MIT Press, vol. 114(3), pp. 769-816, August.

Thaler, Richard H., “Anomalies: Saving, Fungibility and Mental Accounts," Journal of Economic Perspectives, IV (1990), 193-205. 


\section{Variaa}

\section{Agricultural loans $(\%)$}

Curent delinquency rate: Loans delinquent for 30 days or less

Curent delinquency rate: Loans delinquent for more than 30 days

Curent delinquency rate: Total delinquent loan

Delinquency rate (Lag)

Future delinquency rate. Loans delinquent for 30 days or less

Future delinquency rate: Loans delinquent for more than 30 day

Future delinquency rate: Total delinquent loans

acoss the month)

across the month)

Loan officers

Leving we targets

Portofolio size (Lag)

Productivity: Loan renewals placement (biweekly)

Productivity: Loan renewals placement (monthly)

Productivity: New loans placement (biweekly)

Productivity: New loans placement (monthly)

Productivity: Total loans placement (biweekly)

Productivity: Total loans placement (monthly)

Treatment (Nov - Apr)

Treatment (Nov - Jan)

Treatment (Feb - Apr)

Post- Intervention Oct-Dec)

\section{Panel B: Individual level variables}

Age (years)

Dependency (\% house expenses)

Education (years)

Femal

Marital Status

Planning level - change dummy

Planning level - dummy

Satisfaction with compensation - dummy

Satisfaction with compensation - scale (1-5)

Satisfaction with work - dummy

Satisfaction with work - scale (1-5)

Stress (\% of time)

Time working at the bank (months)

Treatment
Number of agricultural loans / total number of outstanding loans (per month)

Number of delinquent loans (deliquent between 1 and 30 days) / number of outstanding loans (per month)

Number of delinquent loans (for more than 30 days) / number of outstanding loans (per month)

Total number of delinquent loans / number of outstanding loans (per month)

That number of delinquent loans / number of outstanding loans (per mont

(delinquent between 1 and 30 days) / number of outstanding loans (per month, two months out)

Namber of delinquent loans (for more than 30 days) / number of outstanding loans (per month, two months out)

(D) months out)

Based on Bancamía expertise, we defined the "ideal" loan sourcing across the month as 35\% of loans placed in the 1st week, $25 \%$ - 2nd week, $20 \%$ - 3rd week and 20\% - 4th week. Given the total number of loans placed in a specific month and the "ideal" theoretical distribution (35\%,25\%, 20\%, 20\%), we computed the "ideal" outcome for each week of that month. For any given week, we then took the difference between the actual loan placement and the "ideal" outcome and squared those

(per month)

Werth in a given office

dor the first, then for the bst two weeks of the month) divided by the number of loan officers before the program started

No. of loan renewals placed (per month) divided by the number of loan officers before the program started

Weekly average of new loans placed (for the first, then for the last two weeks of the month) divided by the number of loan

officers before the program started

No. of new loans placed (per month) divided by the number of loan officers before the program started

Weekly average of total loans placed (for the first, then for the last two weeks of the month) divided by the number of loan

No. of total loans placed (per month) divided by the number of loan officers before the program started

1 for branches in the treatment group during program implementation (November to April), 0 otherwise

1 for branches in the treatment group while incentives were available to loan officers only (November to January), 0 otherwise 1 for branches in the treatment group while incentives were available to loan officers and branch managers (February to April),

1 for branches in the treatment group after the intervention was stopped in April, only available after October and for selected

Age (years) of loan officer during baseline survey

Percentage of household expenses covered by loan officer's income, as reported in baseline survey

Loan officer's education level (years) during baseline survey: 9 yrs - incomplete high-school; 11 yrs - complete high-school; 12 yrs - incomplete technical degree; 13 yrs - complete technical degree or incomplete university degree; 16 yrs - complete (ander of

Gender of loan officer ( 1 if female, 0 if male)

(in survey ( 1 if married or in a non-married live-in relationship, 0 if single, divorce the month. They were given the following choices: 1 ("Yes, I make a detailed plan and usually follow it"), 2 ("Yes, I make a detailed plan, but usually cannot follow it"), 3 ("I don t make plans"). The planning level - change dummy is 1 if the officer repons increasing their cal

The loan officers were asked whether they create and follow a work-plan regarding the distribution of their activities throughou the month. They were given the following choices: 1 ("Yes, I make a detailed plan and usually follow it"), 2 ("Yes, I make a a work plan at the beginning of each month and following it (answer "1" on the planning question), 0 otherwise (answers "2" or

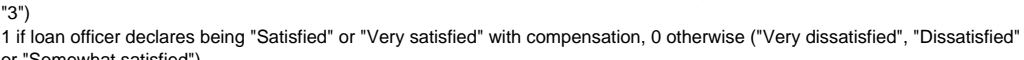

("Satisfied"), 5 ("Very satisfied") 1 if loan officer declares being "Satisfied" or "Very satisfied" with work, 0 otherwise ("Very dissatisfied", "Dissatisfied" or "Somewhat satisfied")

Loan officer's self-reported satisfaction with work: 1 ("Very dissatisfied"), 2 ("Dissatisfied"), 3 ("Somewhat satisfied"), 4 Percentage of the time the loan ofich

icer declares feeling stressed or burned out during the month

1 if observation belongs to the tring at the bank (months) as reported in baseline survey 
Panel A presents the characteristics of all branches in our sample (Total), of those who participated in the incentive program (Treatment) and of those who did not (Control). Column 4 shows the p-values for the hypothesis tests (difference in means and difference in proportions) where the null hypothesis is that the Treatment and Control groups are statistically identical. The summary statistics are based on bank administrative information, and represent averages of monthly data before the program start (July - October 2008).

Panel B presents the personal characteristics of loan officers in all the sample branches (Total), in participating branches (Treatment) and in nonparticipating branches (Control). Column 4 shows the p-values for the hypothesis tests (difference in means and difference in proportions) where the null hypothesis is that the Treatment and Control groups are statistically identical. The summary statistics are based on self-reported information in a telephone survey performed among loan officers in the last two weeks of September 2008

\begin{tabular}{|c|c|c|c|c|}
\hline & Total (1) & Treatment (2) & "Control (3) & Test T-C=0 (4) \\
\hline Variables & $\begin{array}{c}\text { Mean/Proportion } \\
\text { (SD) }\end{array}$ & $\begin{array}{l}\text { Mean/Proportion } \\
\text { (SD) }\end{array}$ & $\begin{array}{l}\text { Mean/ Proportion } \\
\text { (SD) }\end{array}$ & P-values \\
\hline \multicolumn{5}{|l|}{ Panel A: Branch Characteristics } \\
\hline Age of office (months) & $\begin{array}{c}48.04 \\
(52.76)\end{array}$ & $\begin{array}{c}56.50 \\
(57.35)\end{array}$ & $\begin{array}{c}39.30 \\
(46.92)\end{array}$ & 0.2057 \\
\hline Number of credit analysts in office & $\begin{array}{c}6.26 \\
(1.74)\end{array}$ & $\begin{array}{c}6.35 \\
(1.70)\end{array}$ & $\begin{array}{c}6.16 \\
(1.81)\end{array}$ & 0.6636 \\
\hline Office portfolio size (millions of US dollars) & $\begin{array}{c}\$ 2.75 \\
(\$ 1.11)\end{array}$ & $\begin{array}{l}\$ 2.88 \\
(\$ 1.18)\end{array}$ & $\begin{array}{c}\$ 2.61 \\
(\$ 1.04)\end{array}$ & 0.3389 \\
\hline Office portfolio size (no. of credits) & $\begin{array}{c}3104.24 \\
(1067.95)\end{array}$ & $\begin{array}{c}3192.12 \\
(1137.43)\end{array}$ & $\begin{array}{c}3013.43 \\
(1002.28)\end{array}$ & 0.5181 \\
\hline Office portfolio size (no. of credits/analyst) & $\begin{array}{c}501.47 \\
(105.60)\end{array}$ & $\begin{array}{c}512.92 \\
(128.89)\end{array}$ & $\begin{array}{l}489.64 \\
(74.85)\end{array}$ & 0.3940 \\
\hline Rural portfolio (\% of analysts with rural portfolio) & $\begin{array}{l}6.15 \% \\
(0.14)\end{array}$ & $\begin{array}{l}6.01 \% \\
(0.13)\end{array}$ & $\begin{array}{l}6.29 \% \\
(0.16)\end{array}$ & 0.8811 \\
\hline Agricultural credits (as \% of outstanding credits) & $\begin{array}{l}4.44 \% \\
(0.08)\end{array}$ & $\begin{array}{l}4.28 \% \\
(0.07)\end{array}$ & $\begin{array}{l}4.61 \% \\
(0.09)\end{array}$ & 0.8742 \\
\hline Total credits placed per month & $\begin{array}{l}218.23 \\
(68.38)\end{array}$ & $\begin{array}{l}220.25 \\
(66.70)\end{array}$ & $\begin{array}{l}216.15 \\
(71.15)\end{array}$ & 0.8171 \\
\hline New credits placed per month & $\begin{array}{c}99.13 \\
(35.35)\end{array}$ & $\begin{array}{l}101.63 \\
(37.49)\end{array}$ & $\begin{array}{c}96.55 \\
(33.42)\end{array}$ & 0.5791 \\
\hline Credit renewals placed per month & $\begin{array}{l}119.10 \\
(52.55)\end{array}$ & $\begin{array}{l}118.62 \\
(53.47)\end{array}$ & $\begin{array}{l}119.60 \\
(52.49)\end{array}$ & 0.9427 \\
\hline Total credits placed per month/analysts in that office & $\begin{array}{l}35.46 \\
(6.27)\end{array}$ & $\begin{array}{l}35.49 \\
(7.12)\end{array}$ & $\begin{array}{l}35.43 \\
(5.38)\end{array}$ & 0.9740 \\
\hline New credits placed per month/analysts in that office & $\begin{array}{l}16.21 \\
(4.34)\end{array}$ & $\begin{array}{l}16.23 \\
(4.40)\end{array}$ & $\begin{array}{l}16.19 \\
(4.36)\end{array}$ & 0.9735 \\
\hline Credit renewals placed per month/analysts in that office & $\begin{array}{l}19.26 \\
(5.92)\end{array}$ & $\begin{array}{l}19.27 \\
(6.71)\end{array}$ & $\begin{array}{l}19.25 \\
(5.10)\end{array}$ & 0.9916 \\
\hline Credit renewals placed per month (as \% of total credits placed) & $\begin{array}{c}52.86 \% \\
(0.13)\end{array}$ & $\begin{array}{c}52.46 \% \\
(0.15)\end{array}$ & $\begin{array}{c}53.28 \% \\
(0.11)\end{array}$ & 0.8071 \\
\hline Delinquency rate (total) & $\begin{array}{c}11.06 \% \\
(0.03)\end{array}$ & $\begin{array}{c}11.00 \% \\
(0.03)\end{array}$ & $\begin{array}{c}11.12 \% \\
(0.03)\end{array}$ & 0.8842 \\
\hline Delinquency rate (less than 31 days) & $\begin{array}{l}8.75 \% \\
(0.02)\end{array}$ & $\begin{array}{l}8.68 \% \\
(0.02)\end{array}$ & $\begin{array}{l}8.83 \% \\
(0.02)\end{array}$ & 0.8003 \\
\hline Delinquency rate (31 days or more) & $\begin{array}{l}2.31 \% \\
(0.010)\end{array}$ & $\begin{array}{l}2.32 \% \\
(0.012)\end{array}$ & $\begin{array}{l}2.29 \% \\
(0.009)\end{array}$ & 0.8906 \\
\hline No. of observations & 61 & 31 & 30 & \\
\hline \multicolumn{5}{|l|}{ Panel B: Personal Characteristics (Loan Officers) } \\
\hline Age & $\begin{array}{l}29.41 \\
(5.46)\end{array}$ & $\begin{array}{l}29.66 \\
(5.73)\end{array}$ & $\begin{array}{l}29.11 \\
(5.12)\end{array}$ & 0.3181 \\
\hline Percentage women & $\begin{array}{c}46.65 \% \\
(0.50)\end{array}$ & $\begin{array}{c}48.33 \% \\
(0.50)\end{array}$ & $\begin{array}{c}44.69 \% \\
(0.50)\end{array}$ & 0.4746 \\
\hline Percentage of analysts married or in life partnerships & $\begin{array}{c}66.75 \% \\
(0.47)\end{array}$ & $\begin{array}{c}66.51 \% \\
(0.47)\end{array}$ & $\begin{array}{c}67.04 \% \\
(0.47)\end{array}$ & 0.9117 \\
\hline Number of people in the household & $\begin{array}{c}3.50 \\
(1.40)\end{array}$ & $\begin{array}{c}3.60 \\
(1.38)\end{array}$ & $\begin{array}{c}3.39 \\
(1.42)\end{array}$ & 0.1479 \\
\hline Education (years of study) & $\begin{array}{l}15.08 \\
(1.49)\end{array}$ & $\begin{array}{l}15.15 \\
(1.46)\end{array}$ & $\begin{array}{l}14.99 \\
(1.52)\end{array}$ & 0.2965 \\
\hline Education- complete university & $\begin{array}{c}67.27 \% \\
(0.47)\end{array}$ & $\begin{array}{c}69.38 \% \\
(0.46)\end{array}$ & $\begin{array}{c}64.80 \% \\
(0.48)\end{array}$ & 0.3385 \\
\hline Time working at Bancamía (months) & $\begin{array}{c}19.89 \\
(18.83)\end{array}$ & $\begin{array}{c}19.87 \\
(21.63)\end{array}$ & $\begin{array}{c}19.92 \\
(14.96)\end{array}$ & 0.9806 \\
\hline Percentage of time stressed & $\begin{array}{c}33.36 \% \\
(0.31)\end{array}$ & $\begin{array}{c}34.93 \% \\
(0.32)\end{array}$ & $\begin{array}{c}31.54 \% \\
(0.29)\end{array}$ & 0.2776 \\
\hline Percentage of loan officers very satisifed with work & $\begin{array}{c}45.88 \% \\
(0.50)\end{array}$ & $\begin{array}{c}44.50 \% \\
(0.50)\end{array}$ & $\begin{array}{c}47.49 \% \\
(0.50)\end{array}$ & 0.5559 \\
\hline Percentage of loan officers very satisfied with compensation & $\begin{array}{c}27.60 \% \\
(0.45)\end{array}$ & $\begin{array}{c}27.80 \% \\
(0.45)\end{array}$ & $\begin{array}{c}27.37 \% \\
(0.45)\end{array}$ & 0.9250 \\
\hline Percentage of loan officers who make a monthly work plan and follow it & $\begin{array}{c}46.91 \% \\
(0.50)\end{array}$ & $\begin{array}{c}42.58 \% \\
(0.50)\end{array}$ & $\begin{array}{c}51.96 \% \\
(0.50)\end{array}$ & 0.0652 \\
\hline Total wage (bonus plus basic wage) (US dollars) & $\begin{array}{l}\$ 799 \\
(\$ 264)\end{array}$ & $\begin{array}{l}\$ 786 \\
(\$ 260)\end{array}$ & $\begin{array}{c}\$ 814 \\
(\$ 268)\end{array}$ & 0.3087 \\
\hline No. of observations & 388 & 209 & 179 & \\
\hline
\end{tabular}




\section{Table 2. Madrugador Program Impact on Performace}

This table reports regression results on the determinants of program performance. The first performance measure used as dependent variable is the number of officers per branch achieving the weekly loan placement targets. For treatment branches, this variable represented the number of officers winning weekly prizes for achieving the program goals every month. In control branches, officers were not pursuing any program goals nor were receiving prizes, but the same numerical targets were used for computing the dependent variable.The second performance measure is a Gap Indicator defined as the distance between the actual loan placement outcome and the ideal distribution of loan sourcing across the month. The independent variables are program dummies and branch characteristics, all described in Table A1. This analysis uses administrative data obtained directly from the bank. All regressions are estimated using OLS allowing for stantard erros to

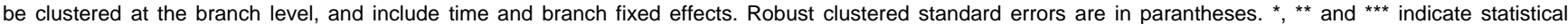
significance for $10 \%, 5 \%$ and $1 \%$ significance levels, respectively.

\begin{tabular}{|c|c|c|c|c|c|c|c|c|c|c|}
\hline & $\begin{array}{c}\text { Depende } \\
\text { (1) }\end{array}$ & $\begin{array}{c}\text { iable is I } \\
\text { (2) }\end{array}$ & $\begin{array}{l}\text { fficers ac } \\
\text { s } \\
\quad \text { (3) }\end{array}$ & $\begin{array}{c}\text { g weekly } \\
\text { (4) }\end{array}$ & $\begin{array}{c}\text { Dependent } \\
\text { (5) }\end{array}$ & $\begin{array}{c}\text { able is Ga } \\
\text { (6) }\end{array}$ & $\begin{array}{l}\text { dicator (dis } \\
\text { ing across } \\
\text { (7) }\end{array}$ & $\begin{array}{l}\text { ece from ic } \\
\text { e month) } \\
(8)\end{array}$ & $\begin{array}{l}\text { (9) distribu } \\
\text { (9) }\end{array}$ & $\begin{array}{l}\text { of of loan } \\
\text { (10) }\end{array}$ \\
\hline Treatment (Nov-Apr) & $\begin{array}{c}0.308 \\
(0.282)\end{array}$ & & $\begin{array}{c}0.391 \\
(0.290)\end{array}$ & & $\begin{array}{l}-6.743^{\star} \\
(3.644)\end{array}$ & & $\begin{array}{l}-6.601^{\star \star} \\
(3.079)\end{array}$ & & $\begin{array}{l}-6.743^{\star} \\
(3.601)\end{array}$ & \\
\hline Treatment (Nov-Jan) & & $\begin{array}{l}-0.081 \\
(0.287)\end{array}$ & & $\begin{array}{l}-0.045 \\
(0.280)\end{array}$ & & $\begin{array}{l}-3.907 \\
(3.873)\end{array}$ & & $\begin{array}{l}-3.541 \\
(3.692)\end{array}$ & & $\begin{array}{l}-3.907 \\
(3.826)\end{array}$ \\
\hline Treatment (Feb-Apr) & & $\begin{array}{l}0.698^{*} \\
(0.373)\end{array}$ & & $\begin{array}{l}0.854^{\star \star} \\
(0.393)\end{array}$ & & $\begin{array}{c}-9.580^{\star \star} \\
(4.390)\end{array}$ & & $\begin{array}{c}-9.837^{\star \star \star} \\
(3.538)\end{array}$ & & $\begin{array}{c}-9.580^{\star \star} \\
(4.336)\end{array}$ \\
\hline Post Intervention (Oct-Dec) & & & & & & & & & $\begin{array}{l}-5.162 \\
(5.264)\end{array}$ & $\begin{array}{l}-5.162 \\
(5.268)\end{array}$ \\
\hline Loan Officers & & & $\begin{array}{c}-0.034 \\
(0.079)\end{array}$ & $\begin{array}{c}-0.036 \\
(0.078)\end{array}$ & & & & & & \\
\hline Agricultural loans (\%) & & & $\begin{array}{c}8.304 \\
(13.090)\end{array}$ & $\begin{array}{c}6.452 \\
(12.555)\end{array}$ & & & $\begin{array}{c}199.761^{\star *} \\
(97.658)\end{array}$ & $\begin{array}{c}212.765^{\star *} \\
(95.848)\end{array}$ & & \\
\hline Portfolio Size (Lag) & & & $\begin{array}{l}0.003^{\star *} \\
(0.001)\end{array}$ & $\begin{array}{c}0.003^{\star * \star} \\
(0.001)\end{array}$ & & & $\begin{array}{c}0.006 \\
(0.011)\end{array}$ & $\begin{array}{c}0.004 \\
(0.011)\end{array}$ & & \\
\hline Delinquency Rate (Lag) & & & $\begin{array}{c}-3.761^{\star *} \\
(1.663)\end{array}$ & $\begin{array}{c}-4.078^{\star \star} \\
(1.613)\end{array}$ & & & $\begin{array}{l}57.424^{\star *} \\
(22.411)\end{array}$ & $\begin{array}{c}59.639^{\star \star \star} \\
(21.895)\end{array}$ & & \\
\hline Constant & $\begin{array}{l}-0.104 \\
(0.089)\end{array}$ & $\begin{array}{l}-0.104 \\
(0.089)\end{array}$ & $\begin{array}{l}-1.954 \\
(2.734)\end{array}$ & $\begin{array}{l}-1.926 \\
(2.640)\end{array}$ & $\begin{array}{c}63.412^{\star \star \star} \\
(3.756)\end{array}$ & $\begin{array}{c}63.412^{\star \star \star} \\
(3.760)\end{array}$ & $\begin{array}{l}-31.644 \\
(21.678)\end{array}$ & $\begin{array}{c}-31.729 \\
(21.134)\end{array}$ & $\begin{array}{c}64.976^{\star \star \star} \\
(3.970)\end{array}$ & $\begin{array}{c}64.9766^{\star \star \star} \\
(3.973)\end{array}$ \\
\hline Observations & 610 & 610 & 549 & 549 & 610 & 610 & 549 & 549 & 793 & 793 \\
\hline R-squared & 0.462 & 0.472 & 0.489 & 0.503 & 0.691 & 0.692 & 0.701 & 0.703 & 0.650 & 0.651 \\
\hline Adj. R-squared & 0.393 & 0.403 & 0.411 & 0.425 & 0.650 & 0.651 & 0.655 & 0.657 & 0.614 & 0.615 \\
\hline Number of clusters & 61 & 61 & 61 & 61 & 61 & 61 & 61 & 61 & 61 & 61 \\
\hline
\end{tabular}


Table 3. Madrugador Program Impact on Productivity

This table reports regression results of the program impact on branch productivity. Productivity is measured as the monthly number of loans placed in a given office divided by the number of loan officers in that office before the start of the program. Results are shown for all loans, new loans and loan renewals, as well as for the number of these loans placed per month, in the first two weeks and in the last two weeks of each month. The independent variables are program dummies, described in Table A1. This analysis uses administrative data obtained directly from the bank. All regressions are estimated using OLS allowing for stantard erros to be clustered at the branch level, and include time and branch fixed effects. Robust clustered standard errors are in parantheses. *, ${ }^{\star \star}$ and ${ }^{\star \star \star}$ indicate statistical significance for $10 \%, 5 \%$ and $1 \%$ significance levels, respectively.

\begin{tabular}{|c|c|c|c|c|c|c|c|c|c|c|c|}
\hline & (1) & (2) ${ }^{\text {Dep }}$ & \multicolumn{8}{|c|}{ cers in the office before the start of the program) } & \\
\hline & \multicolumn{3}{|c|}{ Montly Productivity } & \multicolumn{5}{|c|}{ Productivity Weeks $1 \& 2$} & \multirow{2}{*}{\multicolumn{3}{|c|}{ Productivity Weeks $3 \& 4$}} \\
\hline & & & & & Loan $\mathrm{F}$ & ment Pro & iity on: & & & & \\
\hline & All Loans & New Loans & $\begin{array}{c}\text { Loan } \\
\text { Renewals }\end{array}$ & & & $\mathrm{Ne}$ & & $\begin{array}{c}\text { Loan } \\
\text { Renewals } \\
\end{array}$ & All Loans & New Loans & $\begin{array}{c}\text { Loan } \\
\text { Renewals } \\
\end{array}$ \\
\hline Treatment (Nov-Jan) & $\begin{array}{l}-0.348 \\
(1.650)\end{array}$ & $\begin{array}{c}0.033 \\
(1.177)\end{array}$ & $\begin{array}{l}-0.381 \\
(1.113)\end{array}$ & $\begin{array}{l}0.296 \\
(0.424)\end{array}$ & $\begin{array}{c}0.296 \\
(0.419)\end{array}$ & $\begin{array}{c}0.193 \\
(0.280)\end{array}$ & $\begin{array}{c}0.193 \\
(0.276)\end{array}$ & $\begin{array}{c}0.103 \\
(0.308)\end{array}$ & $\begin{array}{l}-0.410 \\
(0.620)\end{array}$ & $\begin{array}{l}-0.192 \\
(0.400)\end{array}$ & $\begin{array}{l}-0.218 \\
(0.389)\end{array}$ \\
\hline Treatment (Feb-Apr) & $\begin{array}{c}0.509 \\
(1.745)\end{array}$ & $\begin{array}{c}0.737 \\
(1.268)\end{array}$ & $\begin{array}{l}-0.228 \\
(1.053)\end{array}$ & $\begin{array}{l}1.045^{*} \\
(0.594)\end{array}$ & $\begin{array}{l}1.045^{\star} \\
(0.587)\end{array}$ & $\begin{array}{l}0.615^{\star} \\
(0.361)\end{array}$ & $\begin{array}{l}0.615^{*} \\
(0.356)\end{array}$ & $\begin{array}{c}0.429 \\
(0.356)\end{array}$ & $\begin{array}{l}-0.685 \\
(0.661)\end{array}$ & $\begin{array}{l}-0.394 \\
(0.447)\end{array}$ & $\begin{array}{l}-0.291 \\
(0.358)\end{array}$ \\
\hline Post-Intervention (Oct-Dec) & & & & & $\begin{array}{c}0.141 \\
(0.577)\end{array}$ & & $\begin{array}{c}0.387 \\
(0.322)\end{array}$ & & & & \\
\hline Constant & $\begin{array}{c}38.935^{\star \star \star} \\
(0.862)\end{array}$ & $\begin{array}{c}17.052^{\star \star \star} \\
(0.668)\end{array}$ & $\begin{array}{c}21.884^{\star \star \star} \\
(0.611)\end{array}$ & $\begin{array}{c}6.044^{\star \star \star} \\
(0.334)\end{array}$ & $\begin{array}{c}6.085^{\star \star \star} \\
(0.311)\end{array}$ & $\begin{array}{c}2.640^{\star \star \star *} \\
(0.160)\end{array}$ & $\begin{array}{c}2.852^{\star \star *} \\
(0.161)\end{array}$ & $\begin{array}{c}3.404^{\star \star \star} \\
(0.261)\end{array}$ & $\begin{array}{c}13.469 * \star * \\
(0.412)\end{array}$ & $\begin{array}{c}5.857^{\star \star *} \\
(0.265)\end{array}$ & $\begin{array}{c}7.615^{\star \star \star} \\
(0.250)\end{array}$ \\
\hline Observations & 610 & 610 & 610 & 610 & 792 & 610 & 792 & 610 & 610 & 610 & 610 \\
\hline R-squared & 0.752 & 0.674 & 0.815 & 0.592 & 0.544 & 0.565 & 0.573 & 0.712 & 0.735 & 0.620 & 0.784 \\
\hline Adj. R-squared & 0.719 & 0.631 & 0.791 & 0.538 & 0.496 & 0.508 & 0.528 & 0.674 & 0.700 & 0.570 & 0.755 \\
\hline Number of clusters & 61 & 61 & 61 & 61 & 61 & 61 & 61 & 61 & 61 & 61 & 61 \\
\hline
\end{tabular}


Table 4. Madrugador Program Effects on Delinquency Rates

This table reports regression results of the program impact on the quality of loans disbursed in each branch. A good proxy for the quality of the loans disbursed by a given branch is the current or near future delinquency rate of the loans in that branch. Delinquency rate is computed as the number of delinquent loans divided by the total number of outstanding loans, per branch at the end of each month. Results are shown for all delinquent loans, for loans which have been delinquent between 1 and 30 days and for loans which have been delinquent for more than 30 days. The independent variables are program dummies, described in Table A1. This analysis uses administrative data obtained directly from the bank. All regressions are estimated using OLS allowing for stantard erros to be clustered at the branch level, and include time and branch fixed effects. Robust clustered standard errors are in parantheses. ${ }^{*},{ }^{* *}$ and ${ }^{* \star *}$ indicate statistical significance for $10 \%, 5 \%$ and $1 \%$ significance levels, respectively.

\begin{tabular}{|c|c|c|c|c|c|c|}
\hline & $\begin{array}{c}\text { Depend } \\
\text { (1) }\end{array}$ & $\begin{array}{c}\text { Variable is } \\
\text { (2) }\end{array}$ & $\begin{array}{l}\text { elinquency Rat } \\
\text { outstanding loa } \\
\text { (3) }\end{array}$ & $\begin{array}{l}\text { Delinquent } \\
\text { (4) }\end{array}$ & $\begin{array}{l}\text { ans/Total } \\
\text { (5) }\end{array}$ & (6) \\
\hline & \multicolumn{3}{|c|}{ Current Delinquency Rates } & \multicolumn{3}{|c|}{ Future Delinquency (2 Months out) } \\
\hline & Total & $\begin{array}{l}30 \text { days or } \\
\text { less }\end{array}$ & $\begin{array}{c}\text { More than } 30 \\
\text { days }\end{array}$ & Total & $\begin{array}{l}30 \text { days or } \\
\text { less }\end{array}$ & $\begin{array}{c}\text { More than } 30 \\
\text { days }\end{array}$ \\
\hline Treatment (Nov-Jan) & $\begin{array}{c}0.010 \\
(0.007)\end{array}$ & $\begin{array}{c}0.006 \\
(0.006)\end{array}$ & $\begin{array}{c}0.004 \\
(0.003)\end{array}$ & $\begin{array}{c}0.008 \\
(0.009)\end{array}$ & $\begin{array}{c}0.005 \\
(0.008)\end{array}$ & $\begin{array}{c}0.003 \\
(0.002)\end{array}$ \\
\hline Treatment (Feb-Apr) & $\begin{array}{c}0.011 \\
(0.009)\end{array}$ & $\begin{array}{c}0.006 \\
(0.008)\end{array}$ & $\begin{array}{c}0.005 \\
(0.003)\end{array}$ & $\begin{array}{c}0.006 \\
(0.010)\end{array}$ & $\begin{array}{c}0.004 \\
(0.009)\end{array}$ & $\begin{array}{c}0.002 \\
(0.003)\end{array}$ \\
\hline Constant & $\begin{array}{c}0.023^{\star \star \star} \\
(0.003)\end{array}$ & $\begin{array}{c}0.014^{\star \star \star} \\
(0.003)\end{array}$ & $\begin{array}{c}0.009 \star \star \star \\
(0.001)\end{array}$ & $\begin{array}{c}0.026 \star \star \star \\
(0.003)\end{array}$ & $\begin{array}{c}0.022^{\star \star \star} \\
(0.003)\end{array}$ & $\begin{array}{c}0.005^{\star \star \star} \\
(0.001)\end{array}$ \\
\hline Observations & 610 & 610 & 610 & 488 & 488 & 488 \\
\hline R-squared & 0.837 & 0.825 & 0.864 & 0.823 & 0.816 & 0.881 \\
\hline Adj. R-squared & 0.816 & 0.801 & 0.847 & 0.793 & 0.786 & 0.862 \\
\hline Number of clusters & 61 & 61 & 61 & 61 & 61 & 61 \\
\hline
\end{tabular}


Table 5. Madrugador Program Impact on Individual Compensation

This table reports regression results on the determinants of individual compensation. In dividual compensation depends on a base laray and a bonus calculated according to performance (portfolio size and value, and quality). Columns 1-5 use Total Compensation in Colombian pesos as the dependent variable (USD\$1=COP\$2,197 on average for the period). In Column 6 Log of Total Compensation is the dependend variable and in Column 7 Bonus in COP. We used all data avaliable in columns 1-4 and 6-7. Column 5 only includes loan officers for which we had compensation data for seven periods of more between June 2008 and April 2009 (people for whom we have pre and post treatment data). The independent variables are program dummies and loan officer characteristics, all described in Table A1. This analysis uses administrative data obtained directly from the bank, and program survey data. All regressions are estimated using OLS allowing for stantard erros to be clustered at the branch level, and include time and branch fixed effects. Robust clustered standard errors are in parantheses. * ${ }^{* *}$ and ${ }^{* * *}$ indicate statistical significance for $10 \%, 5 \%$ and $1 \%$ significance levels, respectively.

\begin{tabular}{|c|c|c|c|c|c|c|c|}
\hline & \multicolumn{5}{|c|}{ Dependent variable is Total Compensation (Salary + Bonus) } & $\begin{array}{c}\text { Log (Total } \\
\text { Compensation) } \\
(6) \\
\end{array}$ & $\begin{array}{l}\text { Bonus } \\
(7)\end{array}$ \\
\hline $\begin{array}{l}\text { Sample is: Loan officers with } \\
\text { compensation data for: }\end{array}$ & \multicolumn{4}{|c|}{ Any period between June 08 and April 09} & $\begin{array}{l}7 \text { or more } \\
\text { periods }\end{array}$ & \multicolumn{2}{|c|}{$\begin{array}{c}\text { Any period between June } 08 \text { and } \\
\text { April } 09\end{array}$} \\
\hline Treatment (Nov-Apr) & $\begin{array}{l}421,469^{\star \star \star} \\
(45,501)\end{array}$ & $\begin{array}{c}334,133^{\star * *} \\
(43,650)\end{array}$ & & & & & \\
\hline Treatment (Nov-Jan) & & & $\begin{array}{c}402,426^{\star \star \star} \\
(49,156)\end{array}$ & $\begin{array}{c}321,658^{\star \star \star} \\
(49,577)\end{array}$ & $\begin{array}{c}177,763^{\star \star *} \\
(49,844)\end{array}$ & $\begin{array}{l}0.356^{\star \star \star} \\
(0.0403)\end{array}$ & $\begin{array}{c}203,042^{\star \star \star} \\
(37,066)\end{array}$ \\
\hline Treatment (Feb-Apr) & & & $\begin{array}{c}439,158^{\star \star \star} \\
(52,208)\end{array}$ & $\begin{array}{c}345,802^{\star \star \star} \\
(48,566)\end{array}$ & $\begin{array}{c}219,222^{\star \star *} \\
(55,484)\end{array}$ & $\begin{array}{l}0.334^{\star * *} \\
(0.0352)\end{array}$ & $\begin{array}{c}228,628^{\star \star \star} \\
(45,954)\end{array}$ \\
\hline Age & & & & & & & \\
\hline Female & & $\begin{array}{c}3,395 \\
(3,557)\end{array}$ & & $\begin{array}{c}3,403 \\
(3,556)\end{array}$ & & & \\
\hline Marital Status & & $\begin{array}{l}95,553^{\star \star} \\
(44,499)\end{array}$ & & $\begin{array}{l}95,494^{\star *} \\
(44,460)\end{array}$ & & & \\
\hline Dependency (\% house expenses) & & $\begin{array}{l}-44,851 \\
(40,699)\end{array}$ & & $\begin{array}{l}-44,829 \\
(40,690)\end{array}$ & & & \\
\hline Education (years) & & $\begin{array}{c}75,404 \\
(61,213)\end{array}$ & & $\begin{array}{c}75,451 \\
(61,195)\end{array}$ & & & \\
\hline Time working at the bank & & $\begin{array}{l}19,086^{*} \\
(11,253)\end{array}$ & & $\begin{array}{l}19,093^{\star} \\
(11,252)\end{array}$ & & & \\
\hline Constant & $\begin{array}{c}1.967 \mathrm{e}+06^{\star \star \star} \\
(40,122)\end{array}$ & $\begin{array}{c}1.311 \mathrm{e}+06^{\star \star \star} \\
(216,023)\end{array}$ & $\begin{array}{l}1.967 \mathrm{e}+06^{\star *}: \\
\quad(40,132)\end{array}$ & $\begin{array}{l}1.311 \mathrm{e}+06^{\star \star *} \\
(216,085)\end{array}$ & $\begin{array}{c}1.875 \mathrm{e}+06^{\star \star \star} \\
(37,524)\end{array}$ & $\begin{array}{l}14.46^{\star \star \star} \\
(0.0292)\end{array}$ & $\begin{array}{c}702,414^{\star \star \star} \\
(29,055)\end{array}$ \\
\hline Observations & 4,716 & 4,701 & 4,716 & 4,701 & 4,320 & 4,716 & 4,951 \\
\hline R-squared & 0.258 & 0.363 & 0.258 & 0.363 & 0.284 & 0.248 & 0.293 \\
\hline Adj. R-squared & 0.247 & 0.352 & 0.247 & 0.352 & 0.272 & 0.237 & 0.282 \\
\hline Number of clusters & 61 & 61 & 61 & 61 & 61 & 61 & 61 \\
\hline
\end{tabular}


Table 6. Madrugador Program Impact on Well Being: Satisfaction levels

This table reports regression results of the program impact on loan officer satisfaction with work and compensation. Results are shown on two types of dependent variables: a dummy that indicates whether the loan officer declares being "satisfied" or "very satisfied" and a categorical variable in which the loan officer rated his satisfaction level from 1 ("very unsatisfied") to 5 ("very satisfied"). The independent variables are program dummies, baseline values of the dependent variables and branch characteristics, as described in Table A1. This analysis uses self-reported information on the loan officers obtained through telephone surveys before and after the program implementation. All regressions are estimated using probit or ordered probit models, allowing for standard errors to be clustered at the branch level. Robust clustered standard errors are in parantheses. *, ** and *** indicate statistical significance for $10 \%$, $5 \%$ and $1 \%$ significance levels, respectively.

\begin{tabular}{|c|c|c|c|c|c|c|c|c|}
\hline \multirow[t]{2}{*}{ Dependent Variable (DV) is: } & \multirow{2}{*}{\multicolumn{2}{|c|}{$\begin{array}{c}\text { Probit } \\
\text { Very satisfied or } \\
\text { satisfied with work } \\
\begin{array}{cc}(1) & (2)\end{array}\end{array}$}} & \multirow{2}{*}{\multicolumn{2}{|c|}{$\begin{array}{l}\text { Ordered Probit } \\
\text { Satisfaction with work } \\
\text { scale (1-5) } \\
\begin{array}{ll}\text { (3) } & \text { (4) }\end{array}\end{array}$}} & \multirow{2}{*}{\multicolumn{2}{|c|}{$\begin{array}{l}\text { Probit } \\
\text { Very satisfied or satisfied } \\
\text { with compensation } \\
\text { (5) }\end{array}$}} & \multirow{2}{*}{\multicolumn{2}{|c|}{$\begin{array}{l}\text { Ordered Probit } \\
\text { Satisfaction with } \\
\text { compensation scale (1-5) } \\
\text { (7) }\end{array}$}} \\
\hline & & & & & & & & \\
\hline Treatment & $\begin{array}{c}0.275 \\
(0.178)\end{array}$ & $\begin{array}{l}0.298^{\star} \\
(0.172)\end{array}$ & $\begin{array}{c}0.200 \\
(0.145)\end{array}$ & $\begin{array}{l}0.238^{\star} \\
(0.135)\end{array}$ & $\begin{array}{c}0.318 \\
(0.194)\end{array}$ & $\begin{array}{l}0.358^{*} \\
(0.199)\end{array}$ & $\begin{array}{l}0.302^{\star *} \\
(0.149)\end{array}$ & $\begin{array}{l}0.310^{\star *} \\
(0.153)\end{array}$ \\
\hline DV at Baseline & $\begin{array}{l}1.268^{\star \star \star} \\
(0.319)\end{array}$ & $\begin{array}{c}1.625^{\star \star \star} \\
(0.336)\end{array}$ & $\begin{array}{l}0.627^{\star \star \star} \\
(0.108)\end{array}$ & $\begin{array}{c}0.708^{\star \star \star} \\
(0.108)\end{array}$ & $\begin{array}{l}0.572^{\star \star \star} \\
(0.196)\end{array}$ & $\begin{array}{l}0.522^{\star \star \star} \\
(0.198)\end{array}$ & $\begin{array}{c}0.444^{\star \star \star} \\
(0.103)\end{array}$ & $\begin{array}{c}0.468^{\star \star \star *} \\
(0.104)\end{array}$ \\
\hline Age & & $\begin{array}{c}0.061^{\star \star \star} \\
(0.022)\end{array}$ & & $\begin{array}{c}0.019 \\
(0.012)\end{array}$ & & $\begin{array}{c}0.010 \\
(0.021)\end{array}$ & & $\begin{array}{c}0.022 \\
(0.016)\end{array}$ \\
\hline Female & & $\begin{array}{l}-0.049 \\
(0.182)\end{array}$ & & $\begin{array}{c}0.172 \\
(0.147)\end{array}$ & & $\begin{array}{l}-0.335^{*} \\
(0.173)\end{array}$ & & $\begin{array}{l}-0.215 \\
(0.151)\end{array}$ \\
\hline Marital Status & & $\begin{array}{l}-0.127 \\
(0.202)\end{array}$ & & $\begin{array}{l}-0.207 \\
(0.152)\end{array}$ & & $\begin{array}{l}-0.212 \\
(0.212)\end{array}$ & & $\begin{array}{l}-0.286^{\star} \\
(0.167)\end{array}$ \\
\hline Dependency (\% house expenses) & & $\begin{array}{c}0.427 \\
(0.310)\end{array}$ & & $\begin{array}{l}0.579^{\star *} \\
(0.248)\end{array}$ & & $\begin{array}{c}0.429 \\
(0.266)\end{array}$ & & $\begin{array}{c}0.171 \\
(0.221)\end{array}$ \\
\hline Education (years) & & $\begin{array}{c}0.071 \\
(0.062)\end{array}$ & & $\begin{array}{c}0.040 \\
(0.052)\end{array}$ & & $\begin{array}{l}-0.008 \\
(0.049)\end{array}$ & & $\begin{array}{c}0.004 \\
(0.046)\end{array}$ \\
\hline Time working at the bank & & $\begin{array}{l}-0.003 \\
(0.004)\end{array}$ & & $\begin{array}{l}-0.001 \\
(0.003)\end{array}$ & & $\begin{array}{c}0.001 \\
(0.004)\end{array}$ & & $\begin{array}{c}0.002 \\
(0.003)\end{array}$ \\
\hline Constant & $\begin{array}{c}-0.638^{\star \star} \\
(0.309)\end{array}$ & $\begin{array}{c}-3.798^{\star \star \star} \\
(1.185)\end{array}$ & & & $\begin{array}{l}-0.035 \\
(0.180)\end{array}$ & $\begin{array}{l}-0.107 \\
(1.038)\end{array}$ & & \\
\hline cut 1 & & & $\begin{array}{c}0.412 \\
(0.555)\end{array}$ & $\begin{array}{l}2.002^{\star} \\
(1.069)\end{array}$ & & & $\begin{array}{l}-0.515 \\
(0.446)\end{array}$ & $\begin{array}{c}0.042 \\
(0.967)\end{array}$ \\
\hline cut 2 & & & $\begin{array}{l}1.013^{\star *} \\
(0.474)\end{array}$ & $\begin{array}{l}2.631^{\star *} \\
(1.069)\end{array}$ & & & $\begin{array}{c}0.180 \\
(0.422)\end{array}$ & $\begin{array}{c}0.750 \\
(0.952)\end{array}$ \\
\hline cut 3 & & & $\begin{array}{c}2.151^{\star \star \star} \\
(0.474)\end{array}$ & $\begin{array}{c}3.815^{\star \star \star} \\
(1.064)\end{array}$ & & & $\begin{array}{c}1.350^{\star \star \star} \\
(0.415)\end{array}$ & $\begin{array}{l}1.949^{\star \star} \\
(0.958)\end{array}$ \\
\hline cut 4 & & & $\begin{array}{l}3.862^{\star \star \star} \\
(0.498)\end{array}$ & $\begin{array}{c}5.594^{\star \star \star *} \\
(1.083)\end{array}$ & & & $\begin{array}{c}3.170^{\star \star \star *} \\
(0.467)\end{array}$ & $\begin{array}{c}3.828^{\star \star \star \star} \\
(0.965)\end{array}$ \\
\hline Observations & 254 & 254 & 254 & 254 & 252 & 252 & 252 & 252 \\
\hline Pseudo R-squared & 0.067 & 0.124 & 0.057 & 0.084 & 0.042 & 0.070 & 0.053 & 0.074 \\
\hline Number of clusters & 61 & 61 & 61 & 61 & 61 & 61 & 61 & 61 \\
\hline
\end{tabular}


Table 7. Madrugador Program Impact on Well Being: Planning and Stress levels

This table reports regression results of the program impact on loan officer planning behavior and stress levels. Results are shown on two planning level variables: a dummy indicating whether the officer makes a work-plan at the beginning of each month and consequently follows it and a dummy signaling whether the officer's planning level increased or remained at a high level. Stress is measured as percentage of time during the month when the loan officer feels stressed or burned out because of work. The independent variables are program dummies, baseline values of the dependent variables and branch characteristics, as described in Table A1. This analysis uses self-reported information on the loan officers obtained through telephone surveys before and after the program implementation. Planning regressions are estimated using probit models, while stress regressions are estimated using OLS models. All regressions are allowing for standard errors to be clustered at the branch level. Robust clustered standard errors are in parantheses. * ${ }^{* *}$ and ${ }^{\star \star \star}$ indicate statistical significance for $10 \%, 5 \%$ and $1 \%$ significance levels, respectively.

\begin{tabular}{|c|c|c|c|c|c|c|}
\hline \multirow{3}{*}{ Dependent Variable (DV) is: } & \multicolumn{4}{|c|}{ Planning: Probits } & \multirow{2}{*}{\multicolumn{2}{|c|}{$\begin{array}{c}\text { Stress: OLS } \\
\% \text { of time feeling stressed } \\
\text { about work }\end{array}$}} \\
\hline & \multicolumn{2}{|c|}{$\begin{array}{l}\text { Make a plan and } \\
\text { follow it }\end{array}$} & \multicolumn{2}{|c|}{$\begin{array}{l}\text { Planning increased or } \\
\text { stayed high }\end{array}$} & & \\
\hline & $(1)$ & & & & (5) & (6) \\
\hline \multirow[t]{2}{*}{ Treatment } & 0.251 & $0.296^{*}$ & 0.221 & $0.261^{*}$ & $-0.058^{*}$ & -0.054 \\
\hline & $(0.167)$ & $(0.176)$ & $(0.141)$ & $(0.140)$ & $(0.032)$ & $(0.033)$ \\
\hline \multirow[t]{2}{*}{ DV at Baseline } & $0.442^{\star \star \star}$ & $0.486^{\star \star \star}$ & & & $0.461^{\star \star \star}$ & $0.455^{\star \star \star}$ \\
\hline & $(0.168)$ & $(0.179)$ & & & $(0.056)$ & $(0.058)$ \\
\hline \multirow[t]{2}{*}{ Age } & & -0.014 & & -0.004 & & -0.005 \\
\hline & & $(0.017)$ & & $(0.020)$ & & $(0.003)$ \\
\hline \multirow[t]{2}{*}{ Female } & & 0.037 & & $0.391^{* *}$ & & -0.018 \\
\hline & & $(0.174)$ & & $(0.170)$ & & $(0.037)$ \\
\hline \multirow{2}{*}{ Marital Status } & & -0.265 & & 0.050 & & -0.008 \\
\hline & & $(0.167)$ & & $(0.196)$ & & $(0.036)$ \\
\hline \multirow[t]{2}{*}{ Dependency (\%house expenses) } & & 0.483 & & 0.405 & & 0.023 \\
\hline & & $(0.317)$ & & $(0.259)$ & & $(0.045)$ \\
\hline \multirow[t]{2}{*}{ Education } & & 0.075 & & $0.122^{\star \star}$ & & -0.006 \\
\hline & & $(0.048)$ & & $(0.056)$ & & $(0.009)$ \\
\hline \multirow[t]{2}{*}{ Time working at the bank } & & 0.003 & & 0.003 & & -0.000 \\
\hline & & $(0.004)$ & & $(0.004)$ & & $(0.001)$ \\
\hline \multirow[t]{2}{*}{ Constant } & $-0.457^{\star \star \star}$ & -1.324 & $0.501^{\star \star \star}$ & -1.637 & $0.374^{\star \star \star}$ & $0.630^{\star \star \star}$ \\
\hline & $(0.169)$ & $(0.921)$ & $(0.098)$ & $(1.058)$ & $(0.028)$ & $(0.149)$ \\
\hline Observations & 256 & 256 & 256 & 256 & 255 & 255 \\
\hline (Pseudo) R-squared & 0.027 & 0.047 & 0.006 & 0.042 & 0.243 & 0.256 \\
\hline Adj. R-squared & & & & & 0.237 & 0.231 \\
\hline Number of clusters & 61 & 61 & 61 & 61 & 61 & 61 \\
\hline
\end{tabular}




\section{Table 8. Survey Respondents Characteristics}

Of the 388 loan officers interviewed for the baseline survery, 112 had either stopped working in any of the branches in our sample or were otherwise unavailable for the endline survey. 20 loan officers changed program groups (from a Treatment branch to a Control branch or viceversa) for reasons exogenous to the program. These 132 individuals were therefore excluded from the final sample for the individual analysis regressions. Table 5 presents the personal characteristics of all loan officers at baseline and compares the group that responded baseline only (initial group) to the group that responded both baseline and endline surveys (stayers). Column 4 shows the p-values for the hypothesis tests (difference in means and difference in proportions) where the null hypothesis is that both groups are statistically identical. The summary statistics are based on self-reported information in a telephone survey performed among loan officers in the last two weeks of September 2008.

\begin{tabular}{|c|c|c|c|c|}
\hline Variables & $\begin{array}{c}\text { Total } \\
\text { (1) } \\
\text { Mean/Proportion } \\
\text { (SD) }\end{array}$ & $\begin{array}{c}\text { Baseline only } \\
\text { (2) } \\
\text { Mean/Proportion } \\
\text { (SD) }\end{array}$ & $\begin{array}{c}\text { Baseline \& } \\
\text { Endline (3) } \\
\text { Mean/Proportion } \\
\text { (SD) }\end{array}$ & $\begin{array}{c}\text { Test (2)-(3)=0 } \\
\text { (4) } \\
\text { P-values }\end{array}$ \\
\hline \multicolumn{5}{|l|}{ Personal Characteristics } \\
\hline Age & $\begin{array}{l}29.41 \\
(5.46)\end{array}$ & $\begin{array}{l}30.24 \\
(5.92)\end{array}$ & $\begin{array}{l}28.98 \\
(5.17)\end{array}$ & 0.0412 \\
\hline Percentage of analysts married or in life partnerships & $\begin{array}{c}66.75 \% \\
(0.47)\end{array}$ & $\begin{array}{c}62.12 \% \\
(0.49)\end{array}$ & $\begin{array}{c}69.14 \% \\
(0.46)\end{array}$ & 0.1644 \\
\hline Number of people in the household & $\begin{array}{c}3.50 \\
(1.40)\end{array}$ & $\begin{array}{c}3.41 \\
(1.20)\end{array}$ & $\begin{array}{c}3.55 \\
(1.49)\end{array}$ & 0.3132 \\
\hline Education (years of study) & $\begin{array}{l}15.08 \\
(1.49)\end{array}$ & $\begin{array}{l}15.33 \\
(1.34)\end{array}$ & $\begin{array}{l}14.95 \\
(1.54)\end{array}$ & 0.0144 \\
\hline Percentage of time stressed & $\begin{array}{c}33.36 \% \\
(0.31)\end{array}$ & $\begin{array}{c}33.83 \% \\
(0.31)\end{array}$ & $\begin{array}{c}33.13 \% \\
(0.31)\end{array}$ & 0.8339 \\
\hline Percentage of analysts very satisifed with work & $\begin{array}{c}45.88 \% \\
(0.45)\end{array}$ & $\begin{array}{c}43.94 \% \\
(0.46)\end{array}$ & $\begin{array}{c}46.88 \% \\
(0.44)\end{array}$ & 0.5825 \\
\hline Percentage of analysts who make a monthly work plan and follow it & $\begin{array}{c}46.91 \% \\
(0.50)\end{array}$ & $\begin{array}{c}48.48 \% \\
(0.50)\end{array}$ & $\begin{array}{c}46.09 \% \\
(0.50)\end{array}$ & 0.6548 \\
\hline Total wage (bonus plus basic wage) (US dollars) & $\begin{array}{c}\$ 799 \\
(\$ 264)\end{array}$ & $\begin{array}{c}\$ 826 \\
(\$ 266)\end{array}$ & $\begin{array}{c}\$ 785 \\
(\$ 262)\end{array}$ & 0.1496 \\
\hline No. of observations & 388 & 132 & 256 & \\
\hline
\end{tabular}




\section{Table 9. Sample Characteristics}

Table 6 presents the personal characteristics of the 256 loan officers who stayed in our sample and whose observations were thus used for the individual analysis regressions. This table presents results for all loan officers in our final sample (Total), loan officers in participanting branches (Treatment) and in non-participating branches (Control). Column 4 shows the p-values for the hypothesis tests (difference in means and difference in proportions) where the null hypothesis is that the Treatment and Control groups are statistically identical. The summary statistics are based on self-reported information in a telephone survey performed among loan officers in the last two weeks of September 2008.

\begin{tabular}{|c|c|c|c|c|}
\hline Variables & $\begin{array}{c}\text { Total (1) } \\
\text { Mean/Proportion } \\
\text { (SD) }\end{array}$ & $\begin{array}{c}\text { Treatment (2) } \\
\text { Mean/Proportion } \\
\text { (SD) }\end{array}$ & $\begin{array}{c}\text { Control (3) } \\
\text { Mean/Proportion } \\
\text { (SD) }\end{array}$ & $\begin{array}{c}\text { Test T-C }=0 \text { (4) } \\
\text { P-values }\end{array}$ \\
\hline \multicolumn{5}{|l|}{ Personal Characteristics } \\
\hline Age & $\begin{array}{l}28.98 \\
(5.17)\end{array}$ & $\begin{array}{l}29.14 \\
(5.42)\end{array}$ & $\begin{array}{l}28.81 \\
(4.88)\end{array}$ & 0.6073 \\
\hline Percentage of analysts married or in life partnerships & $\begin{array}{c}69.14 \% \\
(0.46)\end{array}$ & $\begin{array}{c}69.12 \% \\
(0.46)\end{array}$ & $\begin{array}{c}69.17 \% \\
(0.46)\end{array}$ & 0.9932 \\
\hline Number of people in the household & $\begin{array}{c}3.55 \\
(1.49)\end{array}$ & $\begin{array}{c}3.70 \\
(1.45)\end{array}$ & $\begin{array}{c}3.38 \\
(1.53)\end{array}$ & 0.0928 \\
\hline Education (years of study) & $\begin{array}{l}14.95 \\
(1.54)\end{array}$ & $\begin{array}{l}14.99 \\
(1.52)\end{array}$ & $\begin{array}{l}14.91 \\
(1.57)\end{array}$ & 0.6642 \\
\hline Percentage of time stressed & $\begin{array}{c}33.13 \% \\
(0.31)\end{array}$ & $\begin{array}{c}36.54 \% \\
(0.32)\end{array}$ & $\begin{array}{c}29.25 \% \\
(0.29)\end{array}$ & 0.0549 \\
\hline Percentage of analysts very satisifed with work & $\begin{array}{c}46.88 \% \\
(0.50)\end{array}$ & $\begin{array}{c}44.85 \% \\
(0.50)\end{array}$ & $\begin{array}{c}49.17 \% \\
(0.50)\end{array}$ & 0.4901 \\
\hline Percentage of analysts very satisfied with compensation & $\begin{array}{c}26.09 \% \\
(0.44)\end{array}$ & $\begin{array}{c}28.57 \% \\
(0.45)\end{array}$ & $\begin{array}{c}23.33 \% \\
(0.42)\end{array}$ & 0.3434 \\
\hline Percentage of analysts who make a monthly work plan and follow it & $\begin{array}{c}46.09 \% \\
(0.50)\end{array}$ & $\begin{array}{c}42.65 \% \\
(0.50)\end{array}$ & $\begin{array}{c}50.00 \% \\
(0.50)\end{array}$ & 0.2389 \\
\hline Total wage (bonus plus basic wage) (US dollars) & $\begin{array}{l}\$ 785 \\
(\$ 262)\end{array}$ & $\begin{array}{l}\$ 774 \\
(\$ 259)\end{array}$ & $\begin{array}{c}\$ 798 \\
(\$ 265)\end{array}$ & 0.4495 \\
\hline
\end{tabular}

